\title{
Phylogeny of the Aplousobranchia (Tunicata: Ascidiacea) ${ }^{1}$
}

\author{
Tatiane R. Moreno ${ }^{2} \&$ Rosana M. Rocha ${ }^{2}$
}

\author{
${ }^{1}$ Contribuition number 1754 of the Departamento de Zoologia, Universidade Federal do Paraná. \\ 2 Laboratório de Biologia e Ecologia de Ascidiacea, Departamento de Zoologia, Universidade Federal do Paraná. \\ Caixa Postal 19020,81531-980 Curitiba, Paraná, Brasil. E-mail: trmoreno@gmail.com; rmrocha@ufpr.br
}

\begin{abstract}
The phylogenetic relationships of genera and families of Aplousobranchia Lahille (Tunicata, Ascidiacea) is reconstructed based on morphological characters - the first comprehensive morphology-based phylogenetic analysis for the Aplousobranchia. Monophyly of Aplousobranchia and its families were tested with samples of 14 families. The final character matrix comprised 47 characters and 41 genera as terminal taxa. Nine equally most parsimonious trees (length $161, \mathrm{Cl}=0.5031, \mathrm{RI}=0.7922$ ) were found. Characters describing replication, colony system formation, and branchial walls were the more important in phylogenetic reconstruction. These characters were more useful than others more traditionally used in ascidian taxonomy, such as: body division, position of the heart, gonads and epicardium. Characters not frequently used in phylogenetic analysis, such as body wall muscles, muscles associated with transversal blood vessels and arrangement of the larval papillae, also have phylogenetic information. Results supported monophyly of the Aplousobranchia sensu Lahille, 1887 including only Polycitoridae, Polyclinidae, and Didemnidae. On the other hand, Aplousobranchia including also Cionidae and Diazonidae is not monophyletic since Perophora and Ecteinascidia were included as ingroups in the cladogram, Ciona (now closer to Ascidia) was no longer included in Aplousobranchia and the position of Rhopalaea and Diazona is not resolved. We propose a revised classification based on this phylogenetic analysis, in which Aplousobranchia, with three new families and an indeterminate taxon, now has 15 families.
\end{abstract}

KEY WORDS. Chordata; classification; morphological characters; systematic; Urochordata.

RESUMO. Filogenia de Aplousobranchia (Tunicata: Ascidiacea). O relacionamento filogenéticos de gêneros e famílias de de Aplousobranchia Lahille (Tunicata,Ascidiacea) foi reconstruída com base em caracteres morfológicos - esta constitui a primeira análise filogenética morfológica abrangente para Aplousobranchia. A monofilia de Aplousobranchia e suas famílias foi testada com espécies de 14 famílias. A matriz final compreendeu 47 caracteres e 41 gêneros como taxons terminais. Nove árvores igualmente parcimoniosas (comprimento 161 passos, $\mathrm{Cl}=0.5031$, RI $=0.7922$ ) foram encontradas. Caracteres descrevendo reprodução, formação de sistemas de zoóides nas colônias e relacionados com a parede da faringe foram os mais importantes na reconstrução filogenética. Estes caracteres apresentaram maior sinal filogenético do que outros mais tradicionalmente utilizados na taxonomia de Ascidiacea como divisão do corpo, posição do coração, gônadas e epicárdio. Caracteres pouco utilizados como musculatura da parede do corpo, musculatura associada aos vasos sanguíneos transversais da faringe e arranjo das papilas adesivas da larva também apresentaram informação filogenética. Os resultados suportam a monofilia de Aplousobranchia sensu Lahille, 1887 incluindo apenas Polycitoridae, Polyclinidae e Didemnidae. Por outro lado, Aplousobranchia incluindo também Cionidae e Diazonidae não é taxon monofilético já que Perophora e Ecteinascidia foram incluídos como grupos internos no cladograma; Ciona (próximo a Ascidia) não pôde ser incluído em Aplousobranchia e não foi possível definir a posição de Rhopalaea e Diazona. Uma classificação revisada baseada nesta análise filogenética é proposta, na qual Aplousobranchia possui 15 famílias, sendo três novas famílias e um táxon indeterminado. PALAVRAS-CHAVE. Caracteres morfológicos; Chordata; classificação; sistemática; Urochordata.

Traditionally, pharynx structure provided the basis for ascidian classification (LahilLe 1887, 1890 in KoTT 1969) while later studies included the position of the gonads (PERRIER 1898 in KoTT 1969). Based on the structure and development of the pharynx, the class is divided into three Orders: Aplousobranchia (flat pharynx without internal longitudinal vessels); Phlebobranchia (flat pharynx, with numerous internal longitudinal vessels); and Stolidobranchia (folded pharynx with internal longitudinal vessels). Using gonad position, the class is divided into two Orders: Enterogona, with the gonads within or below the intestinal loop (includes Aplousobranchia and Phlebobranchia); and Pleurogona, with gonads attached to the body wall (includes Stolidobranchia). 
BERRILL (1936) traced a probable ascidian evolutionary pathway based on the development of the heart, pericardium and epicardium. He suggested that classification based on the pharynx was weak since pharyngeal structure is probably largely due to the size of the organism, and consequently divided the Ascidiacea into Pleurogona and Enterogona. More recently, HiRose (2001), in a study of tunic cell types in 65 ascidians species (including 11 of the 15 traditional ascidian families), showed that two tunic cell types ("tunic bladder cells" and "tunic net cells") supported the Pleurogona and Enterogona division, because they were only found in the Enterogona. Additional analysis, based on $18 \mathrm{~S}$ rDNA sequences (WADA et al. 1992, WADA 1998), also supported this view. In summary, two systems of classification were prominent in the twentieth century: 1) the orders Pleurogona and Enterogona and sub-orders Aplousobranchia, Phlebobranchia and Stolidobranchia (BerRill 1936, 1950, Котт 1985); 2) the Aplousobranchia, Phlebobranchia and Stolidobranchia as orders (VAn NAme 1945, Monniot \& Monniot 1972, Monniot et al. 1991). Monophyly of these groups must be determined to better choose between the two classifications. Here, we test the monophyly of the Aplousobranchia.

The Order Aplousobranchia comprises colonial ascidians, with the body divided into two or three parts (thorax, abdomen and, in some cases, posterior abdomen); with simple oral tentacles and the pharynx with neither folds nor internal longitudinal vessels (VAN NAME 1945). In a comprehensive review of the ascidian genera of the world, MonNiot \& MonNiot (1972) recognized 46 genera of Aplousobranchia in only three families: Polyclinidae, Polycitoridae and Didemnidae. Two additional families, Clavelinidae and Holozoidae, were later accepted (MonNiot \& MonNiot 2001).

Котт $(1969,1985,1990,1992,2001)$, based on long-term surveys of ascidians from Australia and Antarctica, proposed the most important modifications in the traditional classification of the Aplousobranchia: inclusion of Diazonidae, with the genera Rhopalaea Philippi, 1843, Diazona Savigny, 1816, Tylobranchion Herdman, 1886, Syndiazona Oka, 1926 and Pseudodiazona Millar, 1963a; and inclusion of Cionidae, with Ciona Fleming, 1822. Those families belonged previously within the Phlebobranchia Lahille, 1887. She also proposed new families, without describing the phylogenetic methodology to support her new classification. Following her classification, Aplousobranchia includes 14 families (Tab. I), based on replication processes, aspects of the colony and zooid and larval morphology. Котт (1990) redistributed the genera/species of Polycitoridae in five families, believed to be monophyletic. Котт (1992) also re-defined Polyclinidae restricting it to the genera included in the Polyclininae, and suggested five new families. Didemnidae, however, remained stable in various classifications because of the short size of zooids with four or three rows of stigmata, few testis follicles and large larvae being brooded inside the tunic (Lafargue 1983, Lafargue \& Wahl 1987, KotT 1962, 2001), which suggests that this family is indeed a natural group, although its monophyly was never tested.
Very few attempts to reconstruct ascidian phylogeny exist, and the first ones were intuitive and not cladistically based. One of the first comprehensive attempts proposed the origin of a group including Diazona, Rhopalaea, Tylobranchion and the evolution of Aplousobranchia from a Ciona-like ancestor (BERRILL 1936). Following this hypothesis, Didemnidae would have a common origin with Distaplia while Perophoridae is an isolated branch originating directly from Ciona. In the tree produced by this hypothesis, Phlebobranchia was clearly polyphyletic. Котт (1962) proposed an alternative that suggested independent origins for Polycitoridae, Polyclinidae and Didemnidae, each with a Diazonidae-like ancestor, and which would make Aplousobranchia polyphyletic. MilLar (1966) briefly discussed the main lines of ascidian evolution and proposed a phylogenetic tree based exclusively on morphological characters. He suggested that Clavelinidae might have arisen close to the division between Aplousobranchia and Phlebobranchia.

Apart from these few morphological studies, some phylogenetic hypotheses based on specific characters were proposed in various studies. For example, vanadium as a character was proposed by Hawkins et al. (1983). They noted that all the species of Aplousobranchia sensu Lahille and of the families Cionidae and Diazonidae contained significant concentrations of vanadium in its oxidized form (oxidation state IV). This character confirms the proximity of those groups and suggests that they share a common ancestor (Котт 1990), but not necessarily that they form a monophyletic group. In all the Phlebobranchia, vanadium appears in oxidation state III while, in Stolidobranchia, significant levels of vanadium were rarely encountered. Trends in the evolution within each of those taxa seem to be associated with the loss of the element or changes of the oxidation state of vanadium (IV for III).

Recently, accumulating molecular data have shed new light on the phylogenetic relationships within Deuterostomia (Cameron et al. 2000, Turbeville et al. 1994, Swalla et al. 2000, SWALLA 2001) and within Ascidiacea (WADA et al. 1992, WADA 1998, Stach \& Turbeville 2002, Turon \& López-Legentil 2004). Analysis based on 18S rDNA sequences (WADA et al. 1992, WADA 1998) inferred that Enterogona (including only Phlebobranchia) is more closely related to Thaliacea than to Stolidobranchia (WADA 1998), which implies that Ascidiacea is itself not monophyletic. The combined analysis with molecular data (18S rDNA) and morphological characters also showed that Phlebobranchia (including Ascidia, Perophora and Ciona) is a sister-group of Thaliacea and that Aplousobranchia is suggested as a sister-group of Appendicularia (Stach \& Turbeville 2002). On the other hand, Turon \& López-Legentil (2004) focused on the Aplousobranchia, using partial COI sequences of 28 species of ascidians (21 in Aplousobranchia) to reconstruct the phylogeny of the group. Aplousobranchia was shown to be monophyletic with an uncertain relationship with the other two orders.

Here, we test the monophyly of Aplousobranchia and of the families therein. We also propose a phylogenetic recon- 
Table I. Traditional classification of families and genera in the Order Aplousobranchia. Numbers in parentheses indicate the approximate number of species in the genus.

\begin{tabular}{|c|c|c|}
\hline VAN Name (1945) & MoNNIOT \& MONNIOT (1972); MoNNIOT et al. (1991) & Котт $(1990,1992,2001)$ \\
\hline Synoicidae Milne-Edwards, 1841 & Polyclinidae Milne-Edwards, 1841 & Polyclinidae Milne-Edwards, 1841 \\
\hline Polyclinum Savigny, 1816 (34) & Polyclinum Savigny, 1816 & Polyclinum Savigny, 1816 \\
\hline Synoicum Phipps, 1774 (76) & Synoicum Phipps, 1774 & Synoicum Phipps, 1774 \\
\hline Amaroucium Milne-Edwards, 1841 (3) & Aplidium Savigny, 1816 (217) & Aplidium Savigny, 1816 \\
\hline Aplidiopsis Savigny, 1816 (14) & Aplidiopsis Lahille, 1890 & Aplidiopsis Lahille, 1890 \\
\hline Pharyngodictyon Herdman, 1886 & Sidneioides Kesteven, 1909 (4) & Sidneioides Kesteven, 1909 \\
\hline Euherdmania Ritter, 1904 (10) & Sidnyum Savigny, 1816 (13) & Morchellium Giard, 1872 (3) \\
\hline \multirow[t]{11}{*}{ Sigillinaria Oka, 1933 (5) } & Atopogaster Herdman, 1886 (1) & Placentelidae Kott, 1992 \\
\hline & Placentela Redikorzev, 1913 (2) & Placentela Redikorzev, 1913 \\
\hline & Homoeodistoma Redikorzev, 1927(3) & Ritterellidae Kott, 1992 \\
\hline & Ritterella Harant, 1931 (24) & Ritterella Harant, 1931 \\
\hline & Dumus Brewin, 1952 (2) & Dumus Brewin, 1952 \\
\hline & Pharyngodictyon Herdman, 1886 (6) & Euherdmaniidae Ritter, 1904 \\
\hline & Euherdmania Ritter, 1904 & Euherdmania (Ritter, 1903) \\
\hline & Polyclinella Harant, 1930 (1) & Pseudodistomidae Kott, 1992 \\
\hline & Pseudodistoma Michaelsen, 1924 (29) & Pseudodistoma Michaelsen, 1924 \\
\hline & Protopolyclinum Millar, 1960 (1) & Anadistoma Kott, 1992 (1) \\
\hline & Citorclinum Monniot \& Millar, 1988 (1) & Protopolyclinidae Kott, 1992 \\
\hline Didemnidae Verrill, 1871 & Didemnidae Verrill, 1871 & Monniotus Millar, 1988 (5) \\
\hline Echinoclinum Van Name, 1902 (5) & Echinoclinum Van Name, 1902 & Condominium Kott, 1992 (1) \\
\hline Didemnum Savigny, 1816 (65) & Askonides Kott, 1962 (2) & Didemnidae Giard, 1872 \\
\hline Trididemnum Della Valle, 1881 (53) & Didemnum Savigny, 1816 & Didemnum Savigny, 1816 \\
\hline Leptoclinides Bjerkan, 1905 (40) & Trididemnum Della Valle, 1881 & Trididemnum Della Valle, 1881 \\
\hline Lissoclinum Verrill, 1871 (42) & Polysyncraton Nott, 1892 (50) & Polysyncraton Nott, 1892 \\
\hline Diplosoma Macdonald, 1859 (38) & Leptoclinides Bjerkan, 1905 & Leptoclinides Bjerkan, 1905 \\
\hline \multirow[t]{6}{*}{ Coelocormus Herdman, 1886} & Lissoclinum Verrill, 1871 & Lissoclinum Verrill, 1871 \\
\hline & Diplosoma Macdonald, 1859 & Diplosoma MacDonald, 1859 \\
\hline & Atriolum Kott, 1983 (3) & Atriolum Kott, 1983 \\
\hline & Botrydemnum Oka, 1933 (1) & Clitella Kott, 2001 (1) \\
\hline & Coelocormus Herdman, 1886 (1) & \\
\hline & Sinecloaca (Michaelsen, 1930) (1) & Polycitoridae Michaelsen, 1904 \\
\hline Polycitoridae Michaelsen, 1904 & Polycitoridae Michaelsen, 1904 & Exostoma Kott, 1990 (1) \\
\hline Polycitor Renier, 1804 (40) & Polycitor Renier, 1804 & Polycitor Renier, 1804 \\
\hline Archidistoma Garstang, 1891 (13) & Polycitorella Michaelsen, 1924 (17) & Polycitorella Michaelsen, 1924 \\
\hline Eudistoma Caullery, 1909 (119) & Eudistoma Caullery, 1909 & Eudistoma Caullery, 1909 \\
\hline Cystodytes Drasche, 1884 (27) & Cystodytes Drasche, 1884 & Cystodytes Drasche, 1884 \\
\hline Clavelina Savigny, 1816 (47) & Tetrazona Michaelsen, 1930 (2) & Brevicollus Kott, 1990 (1) \\
\hline Holozoa Lesson, 1830 (3) & Protoholozoa Kott, 1969 (6) & Clavelinidae Forbes \& Hanley, 1848 \\
\hline Distaplia Della Valle, 1881 (41) & Atapozoa Brewin, 1956 (1) & Nephtheis (Drasche, 1882) (1) \\
\hline Sycozoa Lesson, 1830 (19) & Clavelina Savigny, 1816 & Clavelina Savigny, 1816 \\
\hline
\end{tabular}


Table I. Continued.

\begin{tabular}{|c|c|c|}
\hline VAN Name (1945) & MonNiot \& MonNiOt (1972), MonNiOt et al. (1991) & Котт $(1990,1992,2001)$ \\
\hline & Oxycorynia Drasche, 1882 & Pycnoclavellidae Kott, 1990 \\
\hline & Podoclavella Herdman, 1890 (9) & Euclavella Kott, 1990 (1) \\
\hline & Pycnoclavella Garstang, 1891 & Pycnoclavella Garstang, 1891 (10) \\
\hline & Archidistoma Garstang, 1891 & Holozoidae Berrill, 1950 \\
\hline & Archascidia Julin, 1904 (1) & Polydistoma Kott, 1990 (3) \\
\hline & Distaplia Della Valle, 1881 & Distaplia Della Valle, 1881 \\
\hline & Cyathocormus Oka, 1912 (1) & Sigillina Savigny, 1816 (10) \\
\hline & Hypodistoma Tokioka, 1967 (4) & Hypodistoma Tokioka, 1967 \\
\hline & Dimorpha Pérès, 1946 (1) & Neodistoma Kott, 1990 (1) \\
\hline & Hypsistozoa Brewin, 1953 (3) & Hypsistozoa Brewin, 1953 \\
\hline & Sycozoa Lesson, 1830 & Sycozoa Lesson, 1830 \\
\hline & Millarus Monniot \& Monniot 1987a (1) & \\
\hline & Stomozoa Kott, 1957 (3) & Stomozoidae Kott, 1990 \\
\hline & & Stomozoa Kott, 1957 \\
\hline \multirow[t]{4}{*}{ Ordem Phlebobranchia } & Ordem Phlebobranchia & Cionidae Lahille, 1887 \\
\hline & & Ciona Fleming, 1822 (13) \\
\hline & & Rhopalaea Philippi, 1843 (13) \\
\hline & & Pseudodiazona Millar, 1963a (3) \\
\hline
\end{tabular}

struction and new classification for the group based on morphological characters.

\section{MATERIAL AND METHODS}

\section{Character selection and taxonomic sampling}

Ascidians usually have few characters which are often difficult to access. As soft-body animals, contraction during fixation often alters the shape and size of some structures. Although size of zooid, ratio between thorax and abdomen, length of siphons are characters usually used in the diagnosis of species, they were not used in this analysis because they were variable and depended on the state of contraction of the specimen. With these tendencies in mind, we included the largest number of possible characters, in addition to those traditionally used for diagnoses of the Ascidiacea (Tab. II). Also, no character was arbitrarily left off the analysis. Situations that made us drop a character were: lack of information for most of the taxa (usually occurred with characters of the larva, presence and shape of the pyloric gland), characters too variable (polymorphic) within many genera (such as presence of a stalk, shape of the atrial languet), autapomorphic characters in the level of the genera, characters altered by the fixation process (presence and number of pigmented spots between the lobes of the siphons), characters invariable and therefore uninformative (the pre-pharyngeal groove is $\mathrm{U}$ shape in all taxa of the ingroup, except in the Perophoridae).

The characters were collected initially from the literature. However, many descriptions were incomplete or difficult to obtain. Direct observation of biological material was required, both, to confirm and to complement descriptions in the literature. Studied specimens are deposited in collections of the Department of Zoology at the Federal University of Paraná (DZUP), at the National Museum of Natural History - Smithsonian Institution, Washington, DC, USA (NMNH), at the Museum National d'Histoire Naturelle in Paris, France (MNHN), at the Iziko Museums of Cape Town in South Africa, and at the Instituto Oceanográfico and Instituto de Biociências at the University of São Paulo in Brazil. Specimens were also obtained from private collections in Spain (researcher Elsa Vázquez), now deposited in the collection of the Department of Zoology of Universidade Federal do Paraná.

Species were selected from one to three genera of each of the 14 families that comprise the order Aplousobranchia (following Котт 1990, 1992, 2001, Tab. I). A minimum of three species in each genus were studied with the following selection criteria: 1) the type species of the genus, 2) species of different geographical areas 3) species present in the Brazilian coast.

Of the 103 species, 88 are representative of 34 genera of Aplousobranchia, three of Ascidia Linnaeus, 1767, one of the Ecteinascidia Herdman, 1880, three of the Perophora Wiegmann, 1835 (Phlebobranchia), three of the Pyura Molina, 1782, three of the Molgula Forbes \& Hanley, 1848 (Stolidobranchia), and one species of Branchiostoma (Cephalochordata). In the list of studied species, the type-species of the respective genus is written in bold and the collection locations are in agreement with the current information in the labels of each sample (Appen-

Revista Brasileira de Zoologia 25 (2): 269-298, June, 2008 
Table II. The list of morphological characters used to generate the phylogenetic hypothesis in figure 1.

Character *
1. Life habit
2. Spicules in the tunic
3. Position of the intestinal loop and gonads
in relation to the pharynx
4. Body divisions
5. Colony form
8. Atrial siphon position in colonial forms
11. Oral siphon margin
10. Oral siphon lobe shape
7. Atrial siphon shape
6onitudinal muscle - right side of the

13. Number of longitudinal thoracic muscle

bands or fibers side.

0, Simple: solitary forms that reproduce sexually; 1 , Colonial: compound forms comprising individuals (zooids) that originated by budding (asexually), which stay united by a stolon or common tunic.

Calcareous crystalline and small (usually 10-40 $\mu \mathrm{m}$ ) structures produced in the tunic. 0 , Absent; 1, Present.

0 , Lateral to the pharynx; 1 , Lateral and posterior to the pharynx; 2 , Posterior to the pharynx.

0, Body undivided, sac like: usually globular; 1 , Body divided into thorax (pharynx) and abdomen (digestive tract, gonads and heart); 2, Body divided into thorax (pharynx), abdomen (digestive tract) and posterior abdomen (gonads and heart). 0 , Stalked: colonies comprising a "head" that usually contains the thoracic region of the zooids or the whole zooids and a stalk formed by the common tunic that elevates the animal from the substrate and contains, in some cases, the abdominal and/or the posterior abdominal regions of the zooids (Fig. 2); 1, Globular: colonies taller than wide, attached to the substrate by a smaller surface area (inferior surface; Fig. 3); 2, Cushion: thick colonies ( $5 \mathrm{~mm}$ or more) attached to the substrate by a larger surface are (inferior surface; Fig. 4); 3, Sheet-like: encrusting thin colonies (5 mm or less), attached to the substrate by an extensive area of the tunic (inferior surface; Fig. 5); 4, Expanded encrusting base: colonies with a thick base from which arise digit-like projections (Fig. 6); 5, Stolonic: colony formed by zooids connected at base through stolons. Stolons consist of stolonic vessels covered with tunic (Fig. 7).

0 , Both siphons open on colony surface (Figs 8, 9); 1 , Only oral siphon opens on colony surface: the atrial siphon opens within the tunic in cavities or channels that communicate with the exterior through a cloaca (Fig. 10).

0 , Tubular: the atrial siphon is formed by a cylindrical extension of the body (Figs 11$14) ; 1$, Small aperture: there is no body extension nor tubular siphon, and the atrial opening exposes less than $50 \%$ of the pharynx (Fig. 12); 2, Wide aperture: there is no body extension nor tubular siphon, and the atrial opening exposes more than $50 \%$ of the pharynx (Fig. 13).

0 , Apical (Figs 11, 12); 1, Not apical: in the middle or base of the thorax (Figs 15, 16).

0 , Lobed; 1, Smooth (Fig. 15).

0 , Rounded (Fig. 16); 1, Sharp (Fig. 17); 2, With projections (Fig. 18).

0 , From 11 to $24 ; 1,30$ or more; 2, Eight or less.

0 , From the oral siphon to the base of the thorax; 1 , From the oral siphon to the extremity of the abdomen; 2, From the oral siphon to the extremity of the posterior abdomen; 3, From the oral siphon to the middle of the thorax; 4, Absent or inconspicuous.

14. Orientation of longitudinal thoracic muscle bands

0 , Oblique in relation to the endostyle (Figs 19-20); 1, Parallel in relation to the endostyle (Figs 21-23); 2, Oblique, ramified with anastomoses; bands from the area of the siphons and the inter-siphonal space towards the base of the thorax bend toward the dorsal line or mid-ventral line and become slightly transverse as they become separated in several narrow bands (Fig. 24); 3, Irregular (Fig. 25).

15. Thoracic transverse muscles

16. Dorsal pharyngeal muscle band

17. Abdominal prolongation of the dorsal pharyngeal muscle band

18. Muscular process 0 , Conspicuous (Fig. 26); 1, Absent or inconspicuous.

Narrow muscle bands, one on each side of the body, concentrated in the dorsal area of the pharynx. In the didemnid these bands join to form the muscular process. 0 , Absent; 1, Present (Figs 27, 28).

0 , Absent; 1, Present (Fig. 27).

Also denominated retractor muscle. It is the continuation of the dorsal pharyngeal muscle band (23) and projects into the tunic thereby anchoring the zooid within the colony. 0, Absent; 1, Present (Fig. 28).

Continue

Revista Brasileira de Zoologia 25 (2): 269-298, June, 2008 
Table II. Continued.

\begin{tabular}{|c|c|}
\hline Character * & Character states \\
\hline 19. Transverse pharyngeal muscle & $\begin{array}{l}\text { Transverse muscle bands on the transverse vessels of the pharynx. 0, Absent; } 1 \text {, On all } \\
\text { transverse vessels (Figs } 34,35 \text { ). }\end{array}$ \\
\hline 20. Horizontal rows of pharyngeal stigmata & 0 , Seventy-five or more; 1 , From 5 to $26 ; 2$, Four; 3 , Three. \\
\hline 21. Longitudinal pharyngeal vessels & 0, Complete (Figs 30, 31); 1, Incomplete (Fig. 32); 2, Absent. \\
\hline 22. Parastigmatic vessels & Fine transverse vessels that cross the stigmata. 0 , Absent; 1 , Present. \\
\hline $\begin{array}{l}\text { 23. Branchial papillae associated with } \\
\text { longitudinal vessels }\end{array}$ & $\begin{array}{l}\text { Papillae perpendicular to the plane of the pharynx wall, supporting longitudinal blood } \\
\text { vessels in their junctions with the transverse vessels. } 0 \text {, Present (Fig. 33); } 1 \text {, Absent. }\end{array}$ \\
\hline 24. Vestigial branchial papillae & $\begin{array}{l}\text { Short and rounded papillae not associated with longitudinal vessels. } 0 \text {, Absent; } 1 \text {, } \\
\text { Present (Figs } 34,35 \text { ). }\end{array}$ \\
\hline 25. Prepharyngeal groove & $\begin{array}{l}\text { Ring of one or two membranes that delimit a channel formed by ciliated cells. } \\
\text { Located in the anterior limit of the pharynx. } 0 \text {, Double: two membranes delimit the } \\
\text { channel; } 1 \text {, Simple: one membrane delimits the channel. }\end{array}$ \\
\hline 26. Neural gland opening & $0, \mathrm{C}$ or $\mathrm{U}$ shaped, or irregular; 1 , Circular or oval. \\
\hline 27. Stomach shape & $\begin{array}{l}\text { 0, Tubular stomach with poorly defined intestine (Fig. 36); 1, Oval to rectangular (Figs } \\
\text { 37-39); 2, Kidney shaped (Fig. 40); 3, Trapezoidal (Fig. 41); 4, Rounded (Fig. 42). }\end{array}$ \\
\hline 28. Stomach wall & $\begin{array}{l}\text { 0, Smooth (Figs } 36,39,41,42) ; 1 \text {, Smooth with internal folds (Fig. 43); } 2 \text {, Folded } \\
\text { (Figs } 37,38) ; 3 \text {, With longitudinal ornamentations (Fig. 40); 4, With rounded } \\
\text { ornamentations. }\end{array}$ \\
\hline 29. Stomach position in the alimentary tract & $\begin{array}{l}0 \text {, In the first half of the proximal branch of the gut; } 1 \text {, In the middle of the proximal } \\
\text { branch of the gut; } 2 \text {, In the posterior half of the proximal branch of the gut. }\end{array}$ \\
\hline 30. Posterior stomach & $\begin{array}{l}\text { The posterior stomach is a swollen portion of the median intestine. } 0 \text {, Absent; } 1 \text {, } \\
\text { Present. }\end{array}$ \\
\hline 31. Gastric reservoir & $\begin{array}{l}\text { A vesicle located between and connected to the stomach and distal portion of the } \\
\text { intestine. } 0, \text { Absent; } 1 \text {, Present. }\end{array}$ \\
\hline $\begin{array}{l}\text { 32. Gonad position relative to the abdomen } \\
\text { or posterior abdomen }\end{array}$ & $\begin{array}{l}0, \text { Included in or beside the intestinal loop; } 1 \text {, In the abdomen, below the intestinal } \\
\text { loop; } 2 \text {, In the posterior abdomen; } 3 \text {, In a sac that is separate from the abdomen. }\end{array}$ \\
\hline 33. Ovary and testis position & $\begin{array}{l}0, \text { Ovary in the centre of the testis lobes; } 1 \text {, Ovary anterior to the testis; } 2 \text {, Ovary } \\
\text { posterior to the testis. }\end{array}$ \\
\hline 34. Testis shape & 0, Lobed; 1, Irregular, ramified, elongated; 2, Rounded or pyriform. \\
\hline 35. Sperm duct & $\begin{array}{l}\text { 0, Straight (Figs } 44,45) ; 1 \text {, Spiral in proximal part; distal part straight (Fig. } 46) ; 2 \text {, } \\
\text { Convoluted: proximal part is irregularly curved over the testis; distal part is straight } \\
\text { (Fig. } 47 \text { ). }\end{array}$ \\
\hline 36. Number of testis follicles & 0, More than $10 ; 1$, From 3-6 follicles; 2 , Two follicles; 3 , One follicle. \\
\hline 37. Oocyte number & 0 , More than $30 ; 1$, Fifteen or fewer. \\
\hline 38. Asexual reproduction types & $\begin{array}{l}0 \text {, Strobilization of the abdomen; } 1 \text {, Strobilization of the posterior abdomen; } 2 \text {, } \\
\text { Oesophageal budding; } 3 \text {, Budding of the vascular appendix or vascular stolon. }\end{array}$ \\
\hline 39. Fertilization & 0 , External; 1, Internal (viviparous species). \\
\hline 40. Incubation of embryos & 0, Absent; 1, Present. \\
\hline 41. Place of incubation & 0 , In the atrial cavity or oviduct of the zooid; 1 , In a special pouch; 2 , In the tunic. \\
\hline $\begin{array}{l}\text { 42. Length of the larval trunk from the tip of } \\
\text { the adhesive papillae to the base of the tail. }\end{array}$ & 0, Up to $0.2 \mathrm{~mm} ; 1$, Greater than $0.4 \mathrm{~mm}$. \\
\hline 43. Ectodermal ampullae & $\begin{array}{l}\text { Epidermal evaginations in the anterior region of the larvae, which form lobes at the } \\
\text { base of the adhesive papillae. } 0 \text {, Absent; } 1 \text {, Present (Figs 48-50). }\end{array}$ \\
\hline 44. Structure of the adhesive papillae & $\begin{array}{l}\text { Adhesive papillae are structures that fix the larva to the substrate and are located in } \\
\text { the anterior extremity of the larval trunk. } 0 \text {, Non-everting, conical, adhesive organs } \\
\text { (Fig. 50); 1, Everting, adhesive organs (Figs } 48,49 \text { ). }\end{array}$ \\
\hline 45. Arrangement of adhesive papillae & 0, Triangle (Fig. 50); 1, Linear (Figs 48, 49). \\
\hline 46. Adhesive papillae stalk & $\begin{array}{l}\text { 0, Absent (sessile papillae) (Fig. 48); } 1 \text {, Present (Fig. } 49) ; 2 \text {, Papillae in a peduncular } \\
\text { process: the three papillae have only one peduncle (Fig. } 50 \text { ). }\end{array}$ \\
\hline 47. Vesicles in larval trunk & $\begin{array}{l}\text { Ectodermal projections in the larval trunk, not associated with the adhesive papillae.0, } \\
\text { Absent; } 1 \text {, Present. }\end{array}$ \\
\hline
\end{tabular}

* The number of each character is the same number that appears in the data matrix (Tab. III) and in the cladogram (Fig. 1).

Revista Brasileira de Zoologia 25 (2): 269-298, June, 2008 
dix I). Complementary information for some species was obtained only from literature when it was impossible to locate or to borrow the specimens.

Although the taxa Tylobranchion nordgaardi (Hartmeyer, 1922), Placentela translucida Kott, 1969, Polycitor vitreus (Sars, 1851) and Tetrazona porrecta Millar, 1962 were studied, they were not included in the analysis due to lack of information.

The final character matrix comprised 41 genera (including five suitable genera traditionally out of Aplousobranchia and one from Cephalochordata) and 47 characters (Tab. III).

\section{Phylogenetic analysis}

Phylogenetic relationships among taxa of Aplousobranchia were analyzed following HeNNIG (1966) and WILEY (1981). All identical states within a character were a priori considered homologous in the absence of contrary evidence. The homoplasies (convergences and parallelisms) were determined $a$ posteriori (WILEY 1981).

In the data coding, non-applicable characters were coded as "-" and both, absence and polymorphisms were coded by "?" (NDE Software; PAGE 2000). Characters were treated as nonordered, equally weighted and optimized by the parsimony method following Fitch (1971). Thus, each state can be derived directly from any other and in any sequence, so that only one step is counted for each transformation along the tree. The non-ordered procedure is suggested for the treatment of multiple-state characters (АмовIм 1997).

Trees were constructed under the assumptions of parsimony with PAUP* (Phylogenetic Analysis Using Parsimony), version 4.0b10 (SWOFFoRD 2002), using the following options: heuristic search, TBR ("Branch-swapping algorithm: tree-bisection-reconnection"), random addition sequence with 1000 replicates ("stepwise addition $=$ random Nreps $=1000$ "). A strict consensus tree was generated to show groups that were constant in all the equally parsimonious trees. Zero-length branches were collapsed (MulTrees option in PAUP).

The characters were optimized with ACCTRAN. This option tend to bias the appearance of a character to a very basal position, when the character appear in a taxa whose sister-group was not either comparable or had an unknown state. In this case, we preferred to maintain its first appearance in the taxa itself.

We first built a cladogram with species as terminal taxa, in which most of the genera grouped well. When character states differed between congeneric species they were at first considered absent. Subsequently, analyzing the topography of the retrieved tree it was possible to discover their plesiomorphic states by comparison with the sister taxon at the respective node, the functional outgroup (KORNET \& TURNER 1999). Since we were testing the monophyly of families, we used genera as terminal taxa. Only Polycitor species (with conflicting character states, suggesting that this genus is not monophyletic) were analyzed separately.

In the absence of phylogenetic hypotheses for the sistergroup relationships of Phlebobranchia and Stolidobranchia with Aplousobranchia, we used representatives of both (Pyura and
Molgula in the Stolidobranchia, and Ascidia, Ecteinascidia and Perophora in the Phlebobranchia) as outgroup. We also included Branchiostoma (representing Cephalochordata) as one outgroup. Appendicularia, considered in some analysis as the sister-group of Aplousobranchia (STACH \& TURbEville 2002), was not included because, being planktonic, the body structures were lost or reduced, resulting in insufficient characters for a morphological analysis.

The point of divergence between Cephalochordata and Tunicata (Ascidiacea) was chosen as the root of the cladogram and polarization of the homologous series was determined $a$ posteriori by comparison with the outgroup generated by the analysis (NIXON \& CARPENTER 1993).

The program TreeView (PAgE 1996) was used for preparation of the cladograms. When discussing more derived taxa than those at a particular node we used the following notation: name of the first taxon that appeared in the node followed by the symbol + .

\section{RESULTS}

The final data matrix included 41 terminal taxa and 47 characters ( 24 binary and 23 multiple state (Tabs II and III). Nine equally parsimonious cladograms were generated by PAUP (161 steps, IC $=0.5031, I R=0.7922$ ). The strict consensus tree was generated to summarize the information contained in all the trees (Fig. 1).

The consensus tree shows the position of Diazona and Rhopalaea not resolved (in the trees it appeared either in the base of the Aplousobranchia branch or in the base of the outgroup branch). The taxon Tylobranchion+ is monophyletic, but contains Perophora and Ecteinascidia, traditionally viewed as Phlebobranchia. Both Polycitoridae and Polyclinidae are divided in more taxa and their diagnoses have to be reviewed. Didemnidae is the most derived Aplousobranchia family and it is very stable in all the cladograms retrieved.

\section{DISCUSSION}

\section{Distribution of the characters in the cladogram (Fig. 1, Tabs II and III)}

The solitary habit (1.0) appeared both in the external group (Cephalochordata and Ciona(Ascidia(Pyura+Molgula)) and in the taxa Rhopalaea. While there is no information about the regenerative capacity of Pyura, Molgula and Ascidia, the abdomen of the Ciona intestinalis (Linnaeus, 1767) has the capacity to regenerate a new thoracic area. Rhopalaea crassa (Herdman, 1880 ) and $R$. neapolitana Philippi, 1843 have a thorax that degenerates from time to time and that is replaced by a new one. This regeneration process may be the intermediate condition between simple ascidians and the formation of colonies (Kott, 1981). Colonialism is present in Diazona and in the ingroup and it is one of the most important characters that placed Perophora+ Ecteinascidia in the internal group. 


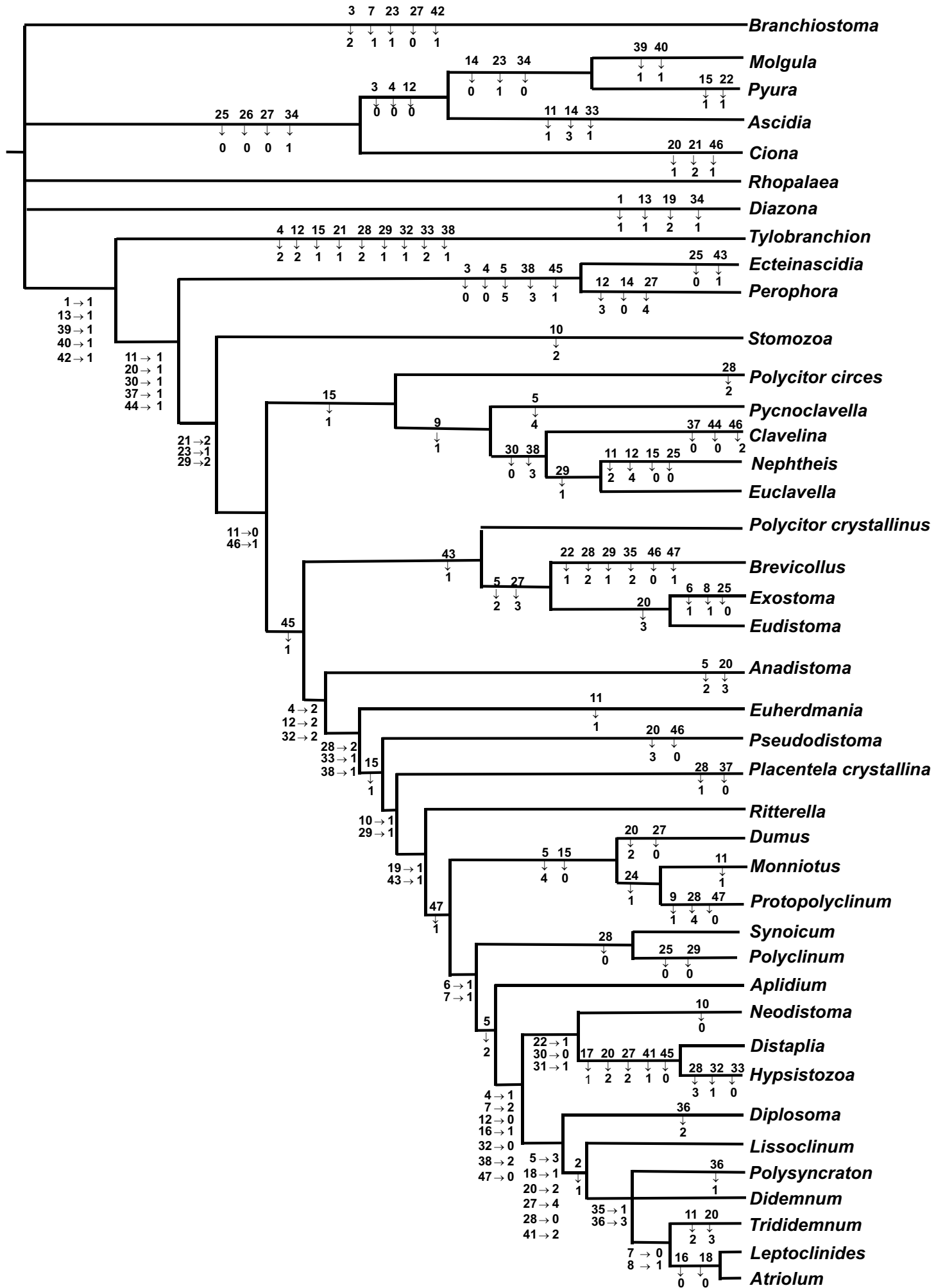

Figure 1. Strict consensus of nine most parsimonious trees (161 steps; $\mathrm{Cl}=0.5031, \mathrm{IR}=0.7922$ ) for 41 taxa of Aplousobranchia (Tunicata, Ascidiacea) and 47 characters.

Revista Brasileira de Zoologia 25 (2): 269-298, June, 2008 
Table III. Character matrix, with the 47 morphological characters and states used in the phylogenetic analysis of the Order Aplousobranchia.

\begin{tabular}{|c|c|c|c|c|c|c|c|c|c|c|c|c|c|c|c|c|c|c|c|c|c|c|c|c|}
\hline Taxon & 1 & 2 & 3 & 4 & 5 & 6 & 7 & 8 & 9 & $\begin{array}{l}1 \\
0\end{array}$ & $\begin{array}{l}1 \\
1\end{array}$ & $\begin{array}{l}1 \\
2\end{array}$ & $\begin{array}{l}1 \\
3\end{array}$ & $\begin{array}{l}1 \\
4\end{array}$ & $\begin{array}{l}1 \\
5\end{array}$ & $\begin{array}{l}1 \\
6\end{array}$ & $\begin{array}{l}1 \\
7\end{array}$ & $\begin{array}{l}1 \\
8\end{array}$ & $\begin{array}{l}1 \\
9\end{array}$ & $\begin{array}{l}2 \\
0\end{array}$ & $\begin{array}{l}2 \\
1\end{array}$ & $\begin{array}{l}2 \\
2\end{array}$ & $\begin{array}{l}2 \\
3\end{array}$ & $\begin{array}{l}2 \\
4\end{array}$ \\
\hline Branchiostoma & 0 & - & 2 & 1 & - & - & 1 & - & 0 & - & - & - & - & $\overline{-}$ & 0 & - & - & - & 0 & 0 & 0 & 0 & 1 & 0 \\
\hline Pyura & 0 & 0 & 0 & 0 & - & - & 0 & - & 0 & 0 & 0 & 0 & 0 & 0 & 1 & 0 & 0 & 0 & 0 & 0 & 0 & 1 & 1 & 0 \\
\hline Molgula & 0 & 0 & 0 & 0 & - & - & 0 & - & 0 & $?$ & 0 & $?$ & $?$ & 0 & 0 & 0 & 0 & 0 & 0 & $?$ & 0 & $?$ & 1 & 0 \\
\hline Ascidia & 0 & 0 & 0 & 0 & - & - & 0 & - & $?$ & $?$ & 1 & 0 & 0 & 3 & 0 & 0 & 0 & 0 & 0 & 0 & 0 & 0 & 0 & 0 \\
\hline Perophora & 1 & 0 & 0 & 0 & 5 & 0 & 0 & 0 & 0 & 0 & 1 & 3 & 1 & 0 & $?$ & 0 & 0 & 0 & 0 & $?$ & $?$ & 0 & 0 & 0 \\
\hline Ecteinascidia & 1 & 0 & 0 & 0 & 5 & 0 & 0 & 0 & $?$ & $?$ & 1 & - & $?$ & $?$ & 0 & 0 & 0 & 0 & 0 & 1 & 0 & 0 & 0 & 0 \\
\hline Ciona & 0 & 0 & 1 & 1 & - & - & 0 & - & 0 & 0 & $?$ & 1 & 0 & 1 & 0 & 0 & 0 & 0 & 0 & 0 & 0 & 0 & 0 & 0 \\
\hline Rhopalaea & 0 & 0 & 1 & 1 & - & - & 0 & - & 0 & 0 & 0 & 1 & 0 & 2 & 1 & 0 & 0 & 0 & 0 & 0 & 0 & 0 & 0 & 0 \\
\hline Diazona & 1 & 0 & 1 & 1 & 0 & 0 & 0 & 0 & 0 & 0 & 0 & 1 & 1 & 2 & 1 & 0 & 0 & 0 & 2 & 0 & 0 & 0 & 0 & 0 \\
\hline Tylobranchion speciosum & 1 & 0 & 1 & 2 & 0 & 0 & 0 & 0 & 0 & 0 & 0 & 2 & 1 & 1 & 1 & 0 & 0 & 0 & 0 & 0 & 1 & 0 & 0 & 0 \\
\hline Stomozoa & 1 & 0 & 1 & 1 & 0 & 0 & 0 & 0 & 0 & 2 & 1 & 1 & 1 & 1 & 0 & 0 & 0 & 0 & 0 & 1 & 2 & 0 & 1 & 0 \\
\hline Polycitor circes & 1 & 0 & 1 & 1 & 0 & 0 & 0 & 0 & 0 & 0 & 0 & 1 & 1 & 1 & 1 & 0 & 0 & 0 & 0 & 1 & 2 & 0 & 1 & 0 \\
\hline Pycnoclavella & 1 & 0 & 1 & 1 & 4 & 0 & 0 & 0 & 1 & - & $?$ & 1 & 1 & 1 & 1 & 0 & 0 & 0 & 0 & 1 & 2 & 0 & 1 & 0 \\
\hline Clavelina & 1 & 0 & 1 & 1 & 0 & 0 & 0 & 0 & 1 & - & $?$ & 1 & 1 & 1 & 1 & 0 & 0 & 0 & 0 & 1 & 2 & 0 & 1 & 0 \\
\hline Euclavella & 1 & 0 & 1 & 1 & 0 & 0 & 0 & 0 & 1 & - & 0 & 1 & 1 & 1 & 1 & 0 & 0 & 0 & $?$ & 1 & 2 & 0 & 1 & 0 \\
\hline Nephtheis & 1 & 0 & 1 & 1 & 0 & 0 & 0 & 0 & 1 & - & 2 & 4 & - & - & 0 & 0 & 0 & 0 & 0 & 1 & 2 & 0 & 1 & 0 \\
\hline Polycitor crystallinus & 1 & 0 & 1 & 1 & 0 & 0 & 0 & 0 & 0 & 0 & 0 & 1 & 1 & 1 & 0 & 0 & 0 & 0 & 0 & 1 & 2 & 0 & 1 & 0 \\
\hline Brevicollus & 1 & 0 & 1 & 1 & 2 & 0 & 0 & 0 & 0 & 0 & $?$ & 1 & 1 & $?$ & $?$ & 0 & 0 & 0 & $?$ & 1 & 2 & 1 & 1 & 0 \\
\hline Exostoma & 1 & 0 & 1 & 1 & 2 & 1 & 0 & 1 & 0 & 0 & 0 & 1 & 1 & 1 & 0 & 0 & 0 & 0 & $?$ & 3 & 2 & 0 & 1 & 0 \\
\hline Eudistoma & 1 & 0 & 1 & 1 & $?$ & 0 & 0 & 0 & 0 & 0 & 0 & 1 & 1 & 1 & 0 & 0 & 0 & 0 & 0 & 3 & 2 & 0 & 1 & 0 \\
\hline Anadistoma & 1 & 0 & 1 & 2 & 2 & 0 & 0 & 0 & 0 & 0 & $?$ & 2 & 1 & 1 & 0 & 0 & 0 & 0 & $?$ & 3 & 2 & 0 & 1 & 0 \\
\hline Euherdmania & 1 & 0 & 1 & 2 & $?$ & 0 & 0 & 0 & 0 & 0 & 1 & 2 & 1 & 1 & 0 & 0 & 0 & 0 & 0 & 1 & 2 & 0 & 1 & 0 \\
\hline Pseudodistoma & 1 & 0 & 1 & 2 & $?$ & 0 & 0 & 0 & 0 & 0 & $?$ & 2 & 1 & 1 & 1 & 0 & 0 & 0 & 0 & 3 & 2 & 0 & 1 & 0 \\
\hline Placentela crystallina & 1 & 0 & 1 & 2 & 0 & 0 & 0 & 0 & 0 & 1 & 0 & 2 & 1 & 1 & 1 & 0 & 0 & 0 & $?$ & 1 & 2 & 0 & 1 & 0 \\
\hline Ritterella & 1 & 0 & 1 & 2 & $?$ & 0 & 0 & 0 & 0 & 1 & 0 & 2 & 1 & 1 & 1 & 0 & 0 & 0 & 1 & 1 & 2 & 0 & 1 & 0 \\
\hline Dumus & 1 & 0 & 1 & 2 & 4 & 0 & 0 & 0 & 0 & 1 & 0 & 2 & 1 & 1 & 0 & 0 & 0 & 0 & $?$ & 2 & 2 & 0 & 1 & 0 \\
\hline Monniotus & 1 & 0 & 1 & 2 & 4 & 0 & 0 & 0 & 0 & 1 & 1 & 2 & 1 & 1 & 0 & 0 & 0 & 0 & 1 & 1 & 2 & 0 & 1 & 1 \\
\hline Protopolyclinum & 1 & 0 & 1 & 2 & 4 & 0 & 0 & 0 & 1 & - & 0 & 2 & 1 & 1 & $?$ & 0 & 0 & 0 & $?$ & 1 & 2 & 0 & 1 & 1 \\
\hline Synoicum & 1 & 0 & 1 & 2 & 0 & 1 & 1 & - & 0 & 1 & 0 & 2 & 1 & 1 & 1 & 0 & 0 & 0 & 1 & 1 & 2 & 0 & 1 & 0 \\
\hline Polyclinum & 1 & 0 & 1 & 2 & $?$ & 1 & 1 & - & 0 & 1 & 0 & 2 & 1 & 1 & 1 & 0 & 0 & 0 & 1 & 1 & 2 & 0 & 1 & 0 \\
\hline Aplidium & 1 & 0 & 1 & 2 & 2 & 1 & 1 & - & 0 & 1 & 0 & 2 & 1 & 1 & 1 & 0 & 0 & 0 & 1 & 1 & 2 & 0 & 1 & 0 \\
\hline Neodistoma & 1 & 0 & 1 & 1 & 2 & 1 & 2 & - & 0 & 0 & $?$ & 0 & 1 & 1 & 1 & $?$ & $?$ & 0 & $?$ & 1 & 2 & 1 & 1 & 0 \\
\hline Distaplia & 1 & 0 & 1 & 1 & 2 & 1 & 2 & - & 0 & 1 & 0 & 0 & 1 & 1 & 1 & 1 & 1 & 0 & 1 & 2 & 2 & 1 & 1 & 0 \\
\hline Hypsistozoa & 1 & 0 & 1 & 1 & $?$ & 1 & 2 & - & 0 & 1 & 0 & 0 & 1 & 1 & 1 & 1 & 1 & 0 & 1 & 2 & 2 & 1 & 1 & 0 \\
\hline Diplosoma & 1 & 0 & 1 & 1 & 3 & 1 & 2 & - & 0 & 1 & 0 & $?$ & $?$ & $?$ & 1 & 1 & 0 & 1 & 1 & 2 & 2 & 0 & 1 & 0 \\
\hline Lissoclinum & 1 & 1 & 1 & 1 & 3 & 1 & 2 & - & 0 & 1 & 0 & 0 & 1 & 1 & 1 & 1 & 0 & $?$ & 1 & 2 & 2 & 0 & 1 & 0 \\
\hline Polysyncraton & 1 & 1 & 1 & 1 & 3 & 1 & 2 & - & 0 & 1 & 0 & 0 & 1 & 1 & 1 & 1 & 0 & 1 & 1 & 2 & 2 & 0 & 1 & 0 \\
\hline Didemnum & 1 & 1 & 1 & 1 & 3 & 1 & 2 & - & 0 & 1 & 0 & 0 & 1 & 1 & 1 & 1 & 0 & 1 & 1 & 2 & 2 & 0 & 1 & 0 \\
\hline Trididemnum & 1 & 1 & 1 & 1 & 3 & 1 & 0 & 1 & 0 & 1 & 2 & 0 & 1 & 1 & 1 & 1 & 0 & 1 & 1 & 3 & 2 & 0 & 1 & 0 \\
\hline Leptoclinides & 1 & 1 & 1 & 1 & 3 & 1 & 0 & 1 & 0 & 1 & 0 & 0 & 1 & 1 & 1 & 0 & 0 & 0 & 1 & 2 & 2 & 0 & 1 & 0 \\
\hline Atriolum & 1 & 1 & 1 & 1 & 3 & 1 & 0 & 1 & 0 & 1 & 0 & 0 & 1 & 1 & 1 & 0 & 0 & 0 & 1 & 2 & 2 & 0 & 1 & 0 \\
\hline
\end{tabular}


Table III. Continued.

\begin{tabular}{|c|c|c|c|c|c|c|c|c|c|c|c|c|c|c|c|c|c|c|c|c|c|c|c|}
\hline Taxon & $\begin{array}{l}2 \\
5\end{array}$ & $\begin{array}{l}2 \\
6\end{array}$ & $\begin{array}{l}2 \\
7\end{array}$ & $\begin{array}{l}2 \\
8\end{array}$ & $\begin{array}{l}2 \\
9\end{array}$ & $\begin{array}{l}3 \\
0\end{array}$ & $\begin{array}{l}3 \\
1\end{array}$ & $\begin{array}{l}3 \\
2\end{array}$ & $\begin{array}{l}3 \\
3\end{array}$ & $\begin{array}{l}3 \\
4\end{array}$ & $\begin{array}{l}3 \\
5\end{array}$ & $\begin{array}{l}3 \\
6\end{array}$ & $\begin{array}{l}3 \\
7\end{array}$ & $\begin{array}{l}3 \\
8\end{array}$ & $\begin{array}{l}3 \\
9\end{array}$ & $\begin{array}{l}4 \\
0\end{array}$ & $\begin{array}{l}4 \\
1\end{array}$ & $\begin{array}{l}4 \\
2\end{array}$ & $\begin{array}{l}4 \\
3\end{array}$ & $\begin{array}{l}4 \\
4\end{array}$ & $\begin{array}{l}4 \\
5\end{array}$ & $\begin{array}{l}4 \\
6\end{array}$ & $\begin{array}{l}4 \\
7\end{array}$ \\
\hline Branchiostoma & 1 & - & 0 & 0 & 0 & 0 & 0 & - & - & 2 & - & 0 & 0 & - & 0 & 0 & - & 1 & 0 & - & - & - & - \\
\hline Pyura & 0 & 0 & 0 & $?$ & 0 & 0 & 0 & - & 0 & 0 & 0 & 0 & 0 & - & 0 & 0 & - & 0 & 0 & 0 & 0 & 0 & 0 \\
\hline Molgula & 0 & $?$ & 0 & 0 & 0 & 0 & 0 & - & 0 & 0 & 0 & 0 & 0 & - & 1 & 1 & 0 & 0 & 0 & - & - & - & 0 \\
\hline Ascidia & 0 & 0 & 0 & $?$ & 0 & 0 & 0 & 0 & 1 & 1 & 0 & 0 & 0 & - & 0 & 0 & - & 0 & 0 & 0 & 0 & 0 & 0 \\
\hline Perophora & 1 & 1 & 4 & 0 & 0 & 1 & 0 & 0 & 0 & 2 & 0 & $?$ & 1 & 3 & 1 & 1 & 0 & 1 & 0 & 1 & 1 & 0 & 0 \\
\hline Ecteinascidia & 0 & 1 & 1 & $?$ & 0 & 1 & 0 & 0 & 0 & 2 & 0 & 0 & 1 & 3 & 1 & 1 & 0 & 1 & 1 & 1 & 1 & 0 & 0 \\
\hline Ciona & 0 & 0 & 0 & $?$ & 0 & 0 & 0 & 0 & 0 & 1 & 0 & 0 & 0 & - & 0 & 0 & - & 0 & 0 & 0 & 0 & 0 & 0 \\
\hline Rhopalaea & 1 & 1 & 1 & 1 & 0 & 0 & 0 & 0 & 0 & 2 & 0 & 0 & 0 & - & 0 & 0 & - & $?$ & $?$ & $?$ & $?$ & $?$ & $?$ \\
\hline Diazona & 1 & 1 & 1 & 1 & 0 & 0 & 0 & 0 & 0 & 1 & 0 & 0 & 0 & 0 & 0 & 0 & - & 0 & 0 & 0 & 0 & 0 & 0 \\
\hline Tylobranchion speciosum & 1 & 1 & 1 & 2 & 1 & 0 & 0 & 1 & 2 & 2 & 0 & 0 & 0 & 1 & 1 & 1 & 0 & 1 & 0 & 0 & 0 & 0 & 0 \\
\hline Stomozoa & 1 & 1 & 1 & 0 & 2 & 1 & 0 & 0 & 0 & 2 & 0 & 0 & 1 & 0 & 1 & 1 & 0 & 1 & $?$ & 1 & 0 & 0 & 0 \\
\hline Polycitor circes & 1 & 1 & 1 & 2 & 2 & 1 & 0 & 0 & 0 & 2 & 0 & 0 & 1 & 0 & 1 & 1 & 0 & 1 & 0 & 1 & 0 & 1 & 0 \\
\hline Pycnoclavella & 1 & 1 & 1 & 0 & 2 & 1 & 0 & 0 & 0 & 2 & 0 & 0 & 1 & $?$ & 1 & 1 & 0 & 1 & 0 & 1 & 0 & 1 & 0 \\
\hline Clavelina & 1 & 1 & 1 & 0 & 2 & 0 & 0 & 0 & 0 & 2 & 0 & 0 & 0 & 3 & 1 & 1 & 0 & 1 & 0 & 0 & 0 & 2 & 0 \\
\hline Euclavella & $?$ & 1 & 1 & 0 & 1 & 0 & 0 & 0 & 0 & 2 & 0 & 0 & 1 & $?$ & 1 & 1 & $?$ & 1 & 0 & 1 & 0 & - & 0 \\
\hline Nephtheis & 0 & 1 & 1 & 0 & 1 & 0 & 0 & 0 & 0 & 2 & 0 & 0 & 1 & 3 & 1 & 1 & 0 & 1 & 0 & 1 & 0 & 1 & 0 \\
\hline Polycitor crystallinus & 1 & 1 & 1 & 0 & 2 & 1 & 0 & 0 & 0 & 2 & 0 & 0 & 1 & 0 & 1 & 1 & 0 & 1 & 1 & 1 & 1 & 1 & 0 \\
\hline Brevicollus & $?$ & $?$ & 3 & 2 & 1 & 1 & 0 & 0 & 0 & 2 & 2 & 0 & 1 & $?$ & 1 & 1 & 0 & 1 & 1 & 1 & 1 & 0 & 1 \\
\hline Exostoma & 0 & 1 & 3 & 0 & 2 & 1 & 0 & 0 & 0 & 2 & 0 & 0 & 1 & $?$ & 1 & 1 & 0 & 1 & 1 & 1 & 1 & 1 & 0 \\
\hline Eudistoma & $?$ & 1 & 3 & 0 & 2 & 1 & 0 & 0 & 0 & 2 & 0 & 0 & 1 & 0 & 1 & 1 & 0 & 1 & 1 & 1 & 1 & 1 & 0 \\
\hline Anadistoma & $?$ & $?$ & 1 & 0 & 2 & 1 & 0 & 2 & 0 & 2 & 0 & 0 & $?$ & $?$ & 1 & $?$ & $?$ & $?$ & $?$ & $?$ & $?$ & $?$ & $?$ \\
\hline Euherdmania & 1 & 1 & 1 & 2 & 2 & 1 & 0 & 2 & 1 & 2 & 0 & 0 & 1 & 1 & 1 & 1 & 0 & 1 & 0 & 1 & - & - & 0 \\
\hline Pseudodistoma & 1 & 1 & 1 & $?$ & 2 & 1 & 0 & 2 & 1 & 2 & 0 & 0 & 1 & 1 & 1 & 1 & 0 & 1 & 0 & 1 & 1 & 0 & 0 \\
\hline Placentela crystallina & $?$ & 1 & 1 & 1 & 1 & 1 & 0 & 2 & $?$ & $?$ & 0 & $?$ & 0 & 1 & 1 & 1 & 0 & 1 & 0 & 1 & 1 & 1 & 0 \\
\hline Ritterella & 1 & $?$ & 1 & 2 & 1 & 1 & 0 & 2 & 1 & 2 & 0 & 0 & 1 & 1 & 1 & 1 & 0 & 1 & 1 & 1 & 1 & 1 & 0 \\
\hline Dumus & $?$ & $?$ & 0 & $?$ & 1 & 1 & 0 & 2 & 1 & 2 & 0 & 0 & 1 & 1 & 1 & 1 & 0 & 1 & 1 & 1 & 1 & 1 & 1 \\
\hline Monniotus & $?$ & 1 & 1 & $?$ & 1 & 1 & 0 & 2 & 1 & 2 & 0 & 0 & 1 & 1 & 1 & 1 & 0 & 1 & 1 & 1 & 1 & 1 & 1 \\
\hline Protopolyclinum & $?$ & 1 & 1 & 4 & 1 & 1 & 0 & 2 & 1 & 2 & 0 & 0 & 1 & 1 & 1 & $?$ & $?$ & 1 & 1 & $?$ & $?$ & $?$ & 0 \\
\hline Synoicum & 1 & 1 & 1 & 0 & 1 & 1 & 0 & 2 & 1 & 2 & 0 & 0 & 1 & 1 & 1 & 1 & $?$ & 1 & $?$ & 1 & 1 & $?$ & 1 \\
\hline Polyclinum & 0 & 1 & 1 & 0 & 0 & 1 & 0 & 2 & 1 & 2 & 0 & 0 & 1 & 1 & 1 & 1 & 0 & 1 & 1 & 1 & 1 & 1 & 1 \\
\hline Aplidium & $?$ & 1 & 1 & 2 & 1 & 1 & 0 & 2 & 1 & 2 & 0 & 0 & 1 & 1 & 1 & 1 & 0 & 1 & 1 & 1 & 1 & 1 & 1 \\
\hline Neodistoma & $?$ & $?$ & 1 & 2 & 1 & 0 & 1 & 0 & $?$ & $?$ & $?$ & $?$ & $?$ & $?$ & 1 & $?$ & $?$ & $?$ & $?$ & $?$ & $?$ & $?$ & ? \\
\hline Distaplia & 1 & 1 & 2 & $?$ & 1 & 0 & 1 & 0 & $?$ & 2 & 0 & 0 & 1 & 2 & 1 & 1 & 1 & 1 & 1 & 1 & 0 & 1 & 0 \\
\hline Hypsistozoa & 1 & $?$ & 2 & 3 & 1 & 0 & 1 & 1 & 0 & 2 & 0 & 0 & 1 & 2 & 1 & 1 & 1 & 1 & 1 & 1 & 0 & 1 & 0 \\
\hline Diplosoma & $?$ & $?$ & 4 & 0 & $?$ & 1 & 0 & 0 & 1 & 2 & 0 & 2 & 1 & 2 & 1 & 1 & 2 & 1 & 1 & 1 & 1 & 1 & 0 \\
\hline Lissoclinum & $?$ & $?$ & 4 & 0 & $?$ & 1 & 0 & 0 & 1 & 2 & 0 & $?$ & 1 & 2 & 1 & 1 & 2 & 1 & 1 & 1 & 1 & 1 & 0 \\
\hline Polysyncraton & $?$ & $?$ & 4 & 0 & 1 & 1 & 0 & 0 & 1 & 2 & 1 & 1 & 1 & 2 & 1 & 1 & 2 & 1 & 1 & 1 & 1 & 1 & 0 \\
\hline Didemnum & $?$ & $?$ & 4 & 0 & 1 & 1 & 0 & 0 & 1 & 2 & 1 & 3 & 1 & 2 & 1 & 1 & 2 & 1 & 1 & 1 & 1 & 1 & 0 \\
\hline Trididemnum & 1 & $?$ & 4 & 0 & 1 & 1 & 0 & 0 & 1 & 2 & 1 & 3 & 1 & 2 & 1 & 1 & 2 & 1 & 1 & 1 & 1 & 1 & 0 \\
\hline Leptoclinides & $?$ & $?$ & 4 & 0 & 1 & 1 & 0 & 0 & 1 & 2 & 1 & 3 & 1 & 2 & 1 & 1 & 2 & 1 & 1 & 1 & 1 & 1 & 0 \\
\hline Atriolum & 1 & 1 & 4 & 0 & 1 & 1 & 0 & 0 & 1 & 2 & 1 & 3 & 1 & 2 & 1 & 1 & 2 & 1 & 1 & 1 & 1 & 1 & 0 \\
\hline
\end{tabular}

Revista Brasileira de Zoologia 25 (2): 269-298, June, 2008 
The presence of spicules in the tunic (2.1) is a synapomorphy for Lissoclinum+. However, spicule recurrence in some species of Eudistoma (E. spiculiferum Millar, 1977) and Cystodytes Drasche, 1884 indicates that the presence of spicules may be homoplasic.

The position of the intestine and gonads posterior to the pharynx (3.2) is observed in Cephalochordata. The bending of the abdomen with the consequent relocation of the anus towards the oral siphon occurred in Tunicata. This bending is more pronounced in animals with sac-like bodies where the alimentary canal and gonads are next to the pharynx (Pyura+ Molgula, Ascidia and Perophora+ Ecteinascidia), but Ciona has an intermediary condition.

Elongated body is a plesiomorphy shared by Cephalochordata and Aplousobranchia. The Ciona+ clade tended towards body length reduction into a sac-like shape (4.0) with the gut next to the pharynx (characteristic of Pyura, Molgula and Ascidia). The body of Ciona has been described as undivided, despite its general appearance (VAn Name 1945, Millar 1970, Monniot \& Monniot 1972). However, we suggest that the alimentary canal and gonads in this genus was considered posterior to the pharynx, following Котт $(1969,1990)$, thereby dividing the body of Ciona into thorax and abdomen, which may be considered as a transition towards the reduction of the later.

In Aplousobranchia, different states evolved: 1. (Perophora+ Ecteinascidia) bended the alimentary tract in a sac-like body (4.0); 2. further elongation of the body with the appearance of a posterior abdomen enclosing the gonads and the heart. Body division (4), broadly used in the traditional classifications, was modified several times in the evolution of the Order Aplousobranchia. The posterior abdomen (4.2) appears twice in the evolutionary history of the Order: in Tylobranchion and in the genera traditionally included in Polyclinidae (Anadistoma+), thus body division is clearly a homoplasic character. Reversion of the state 4.2 (body divided into thorax, abdomen and posterior abdomen) to 4.1 (body divided into thorax and abdomen) can be observed in the clade (Neodistoma(Distaplia+Hypsistozoa))+Diplosoma+. We coded a true posterior abdomen as present (4.2), when the body extended posterior to the abdomen and when the gonads and heart were situated in this body region. Often, the position of the heart in the most subsequent extremity of the abdominal prolongation has been used to identify the posterior abdomen and consequently to define some families of Ascidiacea; however, this structure is difficult or impossible to identify in conserved specimens, thus we accepted published descriptions for this character.

Taxonomists do not concur on body divisions in some genera, but it is generally accepted that the posterior abdomen is the main apomorphy of the traditional family Polyclinidae. In Placentela crystallina Redikorzev, 1913, the heart is clearly located in the abdomen below the intestinal loop and not in the most distal extremity of the abdominal prolongation. $P$. crystallina was first described as not having a posterior abdo- men, but subsequent descriptions found gonads and epicardium sacs within the abdominal prolongation, which was therefore considered a posterior abdomen (Nishikawa 1984). Here we accepted this view. Котт (1990) defined a new family comprising the two known species of Placentela: $P$. crystallina and $P$. translucida Kott, 1969, but the position of the heart in the latter species was not mentioned. Because doubts remained regarding the presence of a true posterior abdomen as defined above for P. translucida, we do not consider this species in the final analysis.

In Tylobranchion speciosum Herdman, 1886 the gonads are located below the intestinal loop and the heart is not distant from the alimentary tract; the epicardium extends beyond the pericardial sacs to the most posterior part of the zooid (Millar 1960). Therefore, this species was coded having a posterior abdomen in this analysis.

In Hypsistozoa, the gonads and the epicardium are placed below the intestinal loop, in the proximal part of the vascular appendix, while the heart is in the abdomen (Котт 1969, 1990). Thus we considered the body divided into thorax and abdomen.

Euherdmania comprises species with and without a posterior abdomen (Котт 1992). The three species used in this analysis have a posterior abdomen and the genus was among other taxa with a posterior abdomen in cladogram retrieved (Fig. 1). A phylogenetic study of this genus is necessary to show whether it is monophyletic (and loss of a posterior abdomen is derived within the genus) or polyphyletic (in which case affinities of the species without the posterior abdomen should be revised).

The more basal colonial genus, Tylobranchion to Stomozoa, form pedunculated colonies (5.0) (Fig. 2), and this shape modified toward an encrusting form, either maintaining the zooids inside projections (Fig. 6) or not (Figs 3-5). Stoloniferous colonies (5.5) appeared only in Perophoridae (Fig. 7).

In several genera of Aplousobranchia a cloaca is absent and both siphons are tubular and open directly on the colony surface (6.0). In the genera in which zooids are organized into systems, a true cloaca exists and the atrial siphons open into these common cavities and only the oral siphons open directly on the surface (6.1) (Figs 8-10). This condition is synapomorphic for the group (Synoicum+Polyclinum)+.

In (Synoicum+Polyclinum) + Aplidium + the atrial aperture is small (7.1) (Fig. 12). The wide atrial opening (7.2) (Fig. 13) is present in ascidians with developed cloacal systems, such as in the clade (Neodistoma(Distaplia + Hypsistozoa))+. It becomes a tubular siphon (7.0) (Fig. 14) in some genera of this last clade: Trididemnum (Leptoclinides+Atriolum). Apical atrial siphons (8.0) are found in the great majority of the internal group, with the exception of Exostoma and Trididemnum+.

The character 9 (oral siphon margin - Figs 15-18) is polymorphic in Ascidia, Ecteinascidia, Hypsistozoa and Leptoclinides. By comparison with functional outgroups, lobed (9.0) is plesiomorphic for Hypsistozoa and Leptoclinides. The oral siphon 

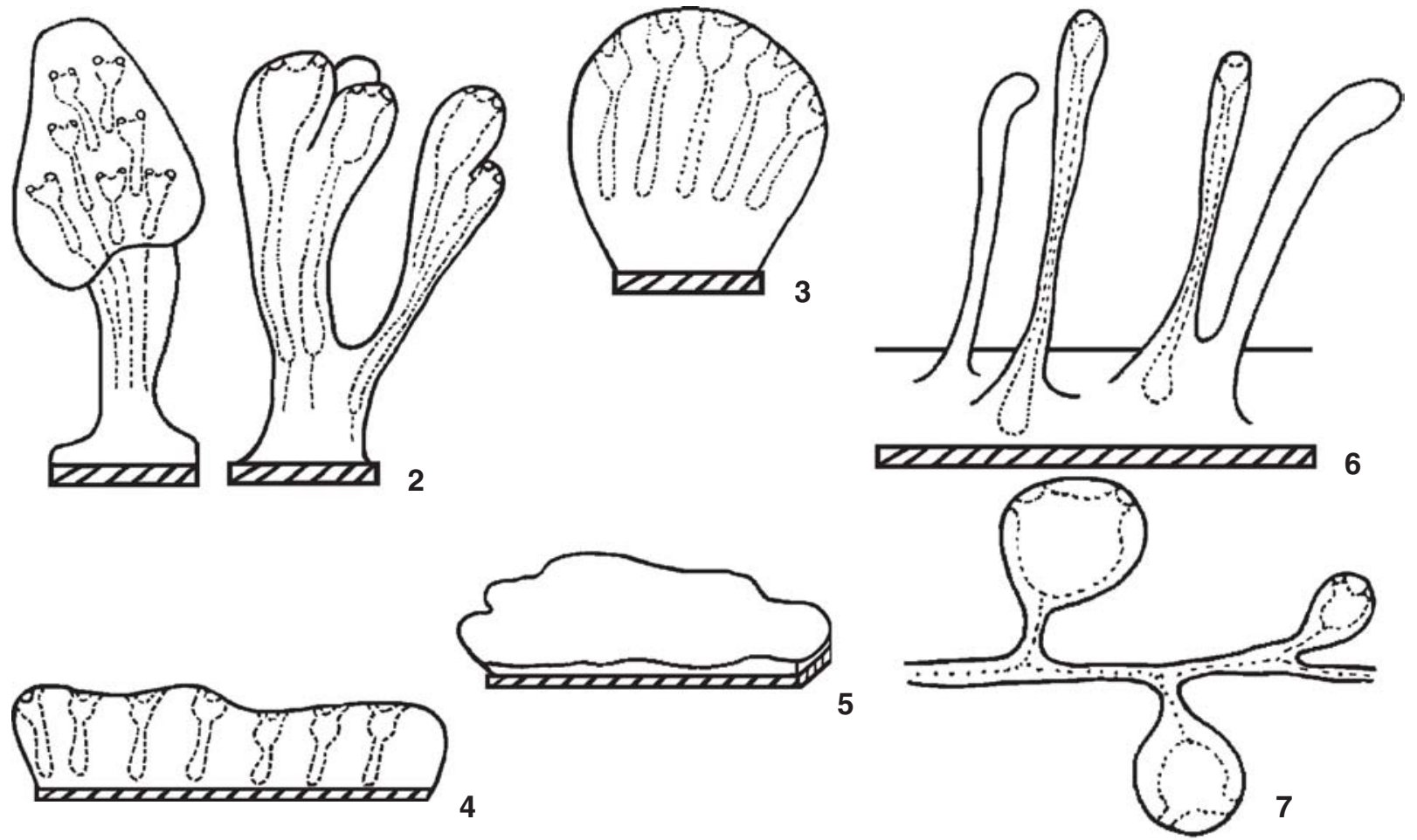

Figures 2-7. Types of colonies: (2) stalked; (3) globular; (4) cushion; (5) sheet; (6) encrusting base; (7) zooids from a stolon.

with a smooth margin (9.1) appears independently in Protopolyclinum and Pycnoclavella(Clavelina (Euclavella+ Nephtheis)). The aspect of the atrial siphon margin is usually similar to the oral siphon margin.

The number of oral tentacles (11) varied, and was polymorphic in Ciona, Pycnoclavella, Clavelina, Eudistoma, Pseudodistoma and Aplidium. In Eudistoma and Aplidium the plesiomorphic state is "from 11 to 24" (11.0). The number of oral tentacles is unrelated to body size or life habit, since Pyura, Diazona, Rhopalaea (relatively large organisms) have a similar number of tentacles with that found in tiny forms, such as Diplosoma+. On the other hand, Ciona, a genus of large solitary ascidians has species with both, a reduced number of tentacles (C. antarctica Hartmeyer, $1911-12$ tentacles and C. pomponiae Monniot \& Monniot, 1989 - 16 tentacles) and species with numerous oral tentacles (C. intestinalis - greater than 50). Perophora (a colonial ascidian) is another example, with individuals of reduced size, which have around 30 oral tentacles (11.1). The state "few oral tentacles" seems to be plesiomorphic, occurring in Diazona and Rhopalaea.

Since many descriptive, especially older, studies do not describe the orientation of the muscle bands, in all specimens the muscle was carefully examined (Figs 19-25). Muscle bands in Pyura and Molgula are oblique in relation to the endostyle, as well as in Perophora+Ecteinascidia. In some species of Molgula, however, muscles are only present in the siphon or extend to- wards the middle of the thorax (12.3). Ascidia have either complete longitudinal muscles, ending at the middle of the thorax or absent. When complete, bands have an irregular distribution (12.3), which is autapomorphic for this genus. "Muscle bands parallel to the endostyle" (12.1) is a homoplasic character and arose independently in Ciona and in Tylobranchion+. Rhopalaea and Diazona have a very unique muscle orientation (12.2).

Transverse muscles on the body wall (15) (Fig. 26) found in Molgula, Ascidia and in Ciona differ from those observed in other taxa of the internal group, in that they are irregular and anastomose in the extremities. The thoracic transverse muscles were lost (15.1) independently several times: in Pyura, Polycitor circes + and Pseudodistoma+. Hence, transverse muscles are present in many basal taxa, disappear and appear again supporting the clade Dumus (Monniotus+Protopolyclinum) in the ingroup. In some genera such as Ascidia, Molgula and Perophora, transverse muscles can be absent in one side, usually the left, and therefore only the right side was included in the analysis.

Dorsal longitudinal muscle band (16.1) (Figs 27 and 28) associated with the pharynx was not previously mentioned in the literature for Distaplia, Hypsistozoa and Neodistoma, and was revealed by the study of the genera Distaplia and Hypsistozoa. In the analysis it supported the position of the clade Neodistoma (Distaplia+Hypsistozoa) as the sister-group of Diplosoma+, even though there is no information of this character for Neodistoma. The relationship between Neodistoma (Distaplia+Hypsistozoa) and

Revista Brasileira de Zoologia 25 (2): 269-298, June, 2008 

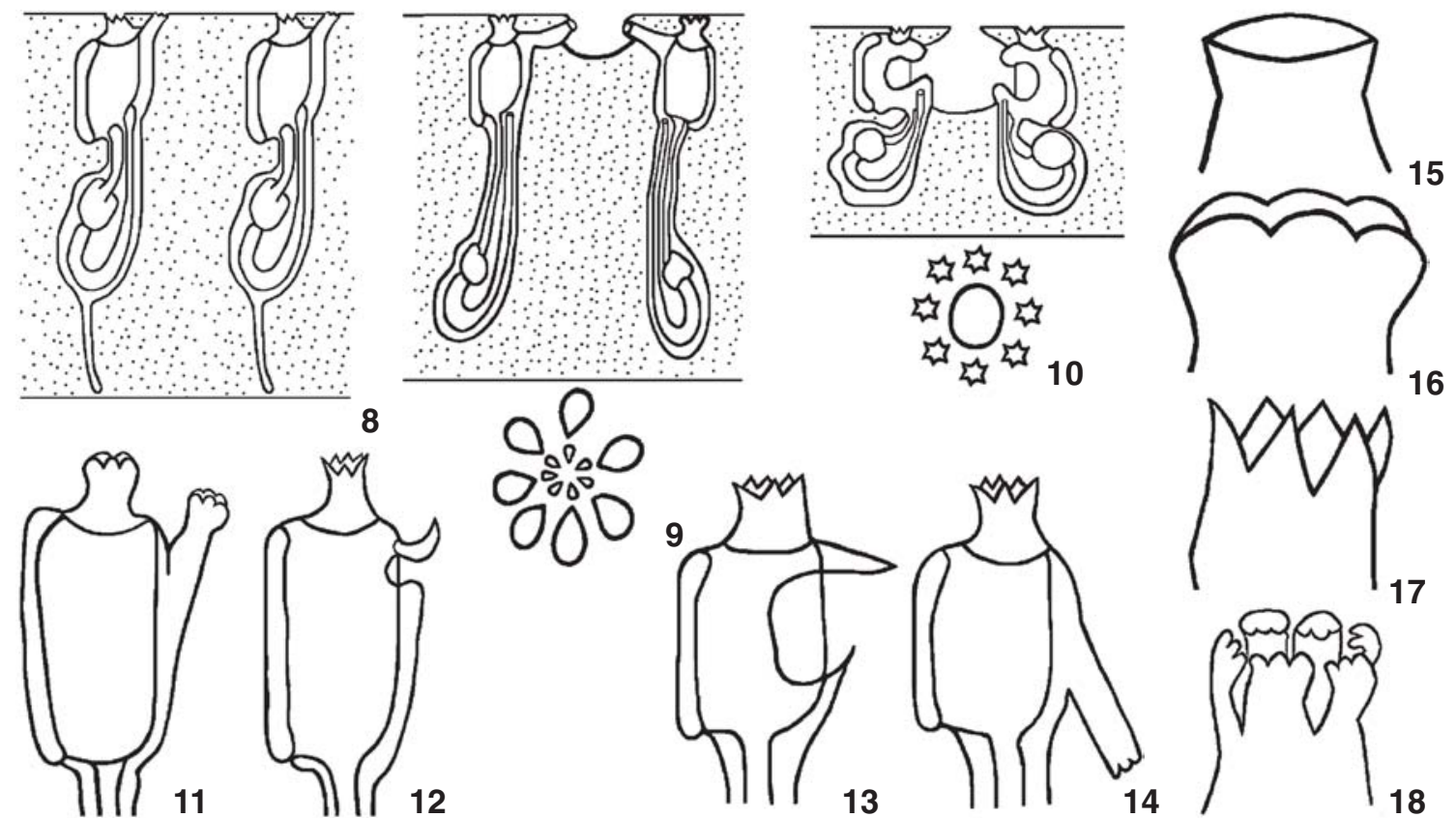

Figures 8-18. (8-10) Openings on the colony surface: (8) both siphons open on colony surface, without cloacal systems, (9) both siphons open on colony surface, the atrial in a depression on the colony surface (rudimentary cloaca) - cross section and view from the colony surface, (10) only oral siphon opens on colony surface: the atrial siphon opens within the tunic in cavities or channels that communicate with the exterior through a cloaca - cross section and view from the colony surface; (11-14) atrial siphon: (11) tubular apical; (12) small and apical; (13) wide; (14) tubular basal; (15-18) oral siphon: (15) margin smooth; (16) margin with rounded lobes; (17) margin with pointed lobes; (18) margin with ramified lobes.

Diplosoma+ was also pointed out by BerRILL (1936) and Hirose (2001). This character appears together with the modification of the atrial siphon forming a wide aperture that exposes a large part of the pharynx. In these taxa, the body wall is reduced and the appearance of this paired muscle band may have reinforced the pharynx. A secondary loss (16.0) of this character occurs in Leptoclinides+Atriolum. Despite further modification of the atrial siphon as a tube in Trididemnum (Leptoclinides+Atriolum), the dorsal muscle pharyngeal band is still present in Trididemnum, but it is lost in the others. The "abdominal prolongation of the dorsal pharyngeal muscle band is present only in Distaplia+Hypsistozoa (17.1) (Fig. 27). This character might have appeared in the base of the clade Neodistoma+. This dorsal muscle pharyngeal band could be equivalent to the muscular process but a more detailed study is necessary to determine homology. The muscular process (18.1) (Fig. 28) is the posterior continuation of the dorsal pharyngeal muscle band that detaches from the body wall. It is a synapomorphy for Diplosoma+, being lost secondarily in Leptoclinides+Atriolum, along with the loss of the dorsal pharyngeal muscle band. Polymorphism for this character occurs only in Lissoclinum.

Beyond the dorsal longitudinal muscle, some genera also present transverse pharyngeal muscle (19.1) (Figs 29, 34 and 35). It arises in Ritterella+, i.e., in ascidians with posterior abdomen, traditionally of Polyclinidae. Euherdmania and Pseudodistoma had no muscle (19.0) and the character state in Placentela crystallina cannot be defined because of the preserved condition of the specimen. "Presence" (19.1) was defined as the plesiomorphic state for Distaplia, which is polymorphic. Recently, this character was described in Didemnidae (Diplosoma+; Kотт 2001). Dumus and Protopolyclinum must be further studied to determine the presence of transverse pharyngeal muscle bands, which would better define the relationship among the taxa of the clade. Transverse muscle bands also occur in Ciona antarctica and in Diazona violacea Savigny, 1816, yet not on all the transverse vessels. The plesiomorphic state for Ciona was defined as "absence" (19.0).

No species were found with between 26 and 74 rows of stigmata, hence we defined the state as 75 rows or more (20.0). This character occurs in genera of simple ascidians (Ciona, Pyura and Ascidia), and in Rhopalaea, Diazona and in the most basal taxon of the internal group Tylobranchion. While "three" and "four" rows of stigmata are congenerically constant, they arise independently in different groups. Three rows (20.3) arose four times: in Exostoma+Eudistoma, in Anadistoma, in Pseudodistoma and in Trididemnum and four rows (20.2) arose in Dumus and in the clade (Neodistoma(Distaplia+Hypsistozoa)+. Reversion to many rows occurs in Neodistoma. Reduction of four to three rows of stigmata is not obligatory. This character is clearly associated with 

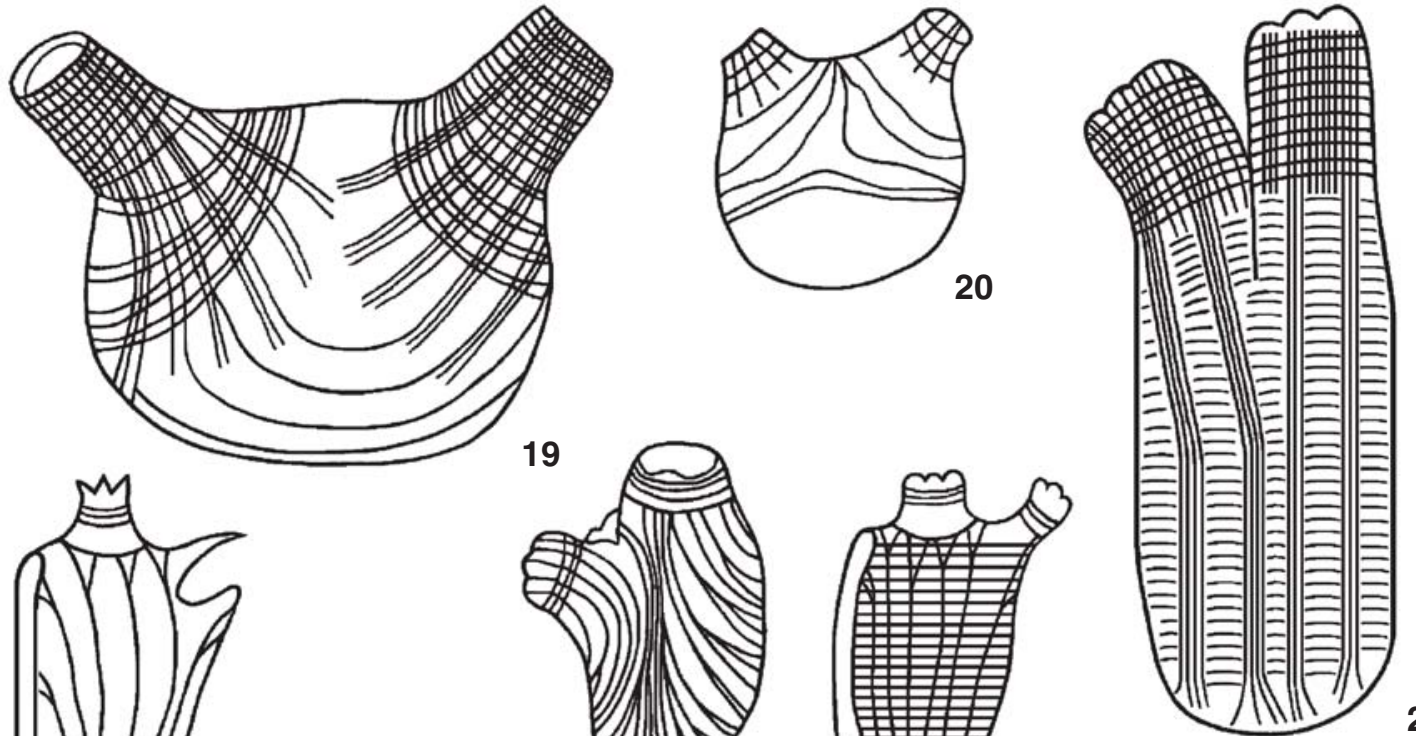

21
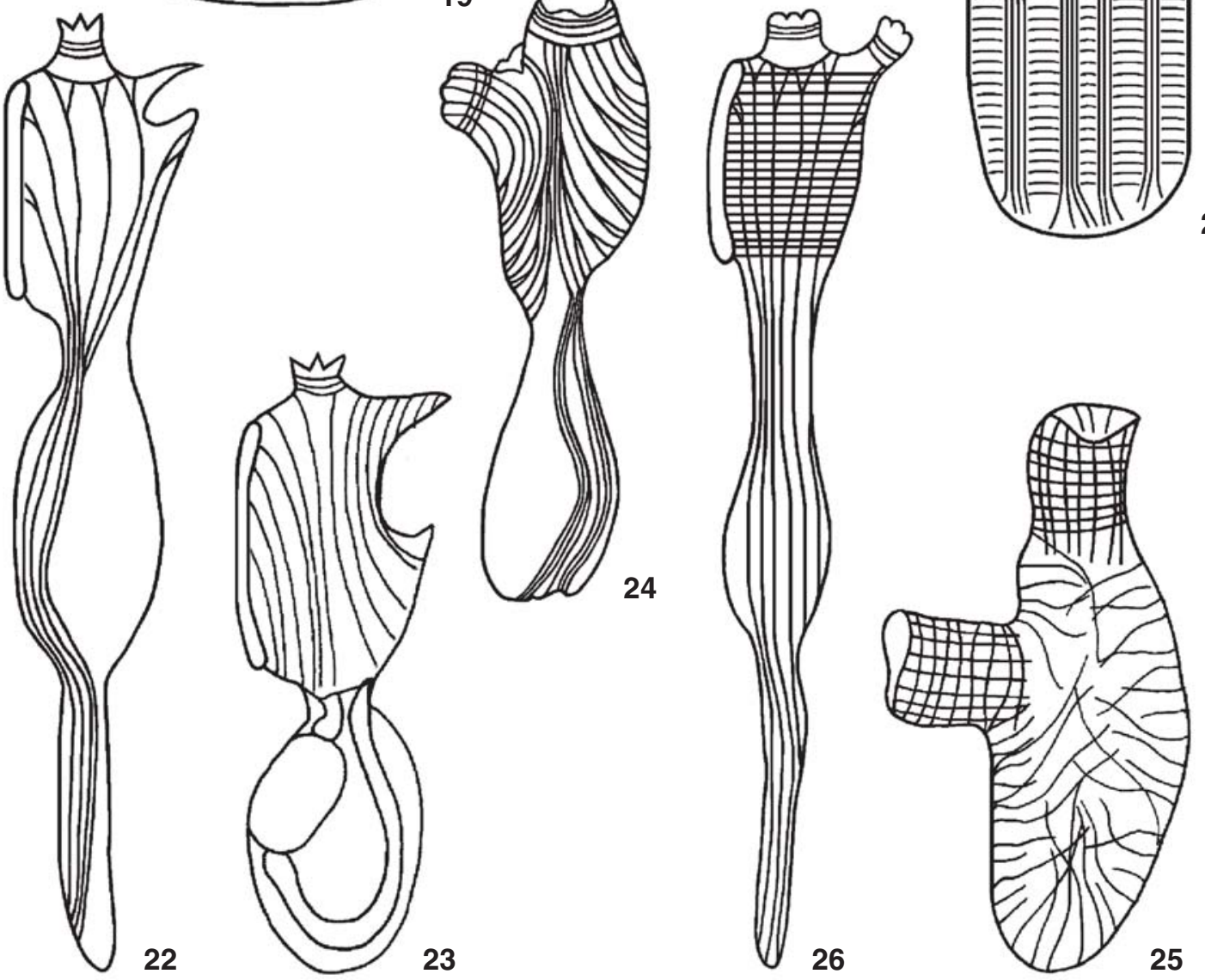

Figures 19-26. Musculature on the body wall: (19-20) oblique to the endostyle; (21-23) parallel to the endostyle; (24) oblique, ramified and anastomosed; (25) irregular; (26) thoracic transversal.

the size of the thorax and the reduction of the number of rows, from state 20.0 (75 rows or more) to 20.1 (5-26 rows) and then to each one of the two other states (20.2 - three rows, or 20.3 - four rows) occurred at different times in the evolution of the group.

The plesiomorphic state "complete longitudinal blood vessels" (21.0) (Figs 30 and 31) is found in Branchiostoma, Ciona+ and in the most basal taxa of the internal group. Rhopalaea and Diazona occasionally present incomplete vessels, but in the studied specimens, the vessels were apparently ruptured and so were treated as complete vessels. Vessels were incomplete (21.1) (Fig. 32) in Tylobranchion speciosum and some species of Perophora, whose internal pharyngeal papillae appear in form of " $\mathrm{T}$ ". Vessels are completely absent (21.2) in the taxa beginning with Stomozoa+.

Parastigmatic vessels (22.1) is homoplasic and arose independently in the genera: Pyura, Brevicollus, and supports the

Revista Brasileira de Zoologia 25 (2): 269-298, June, 2008 

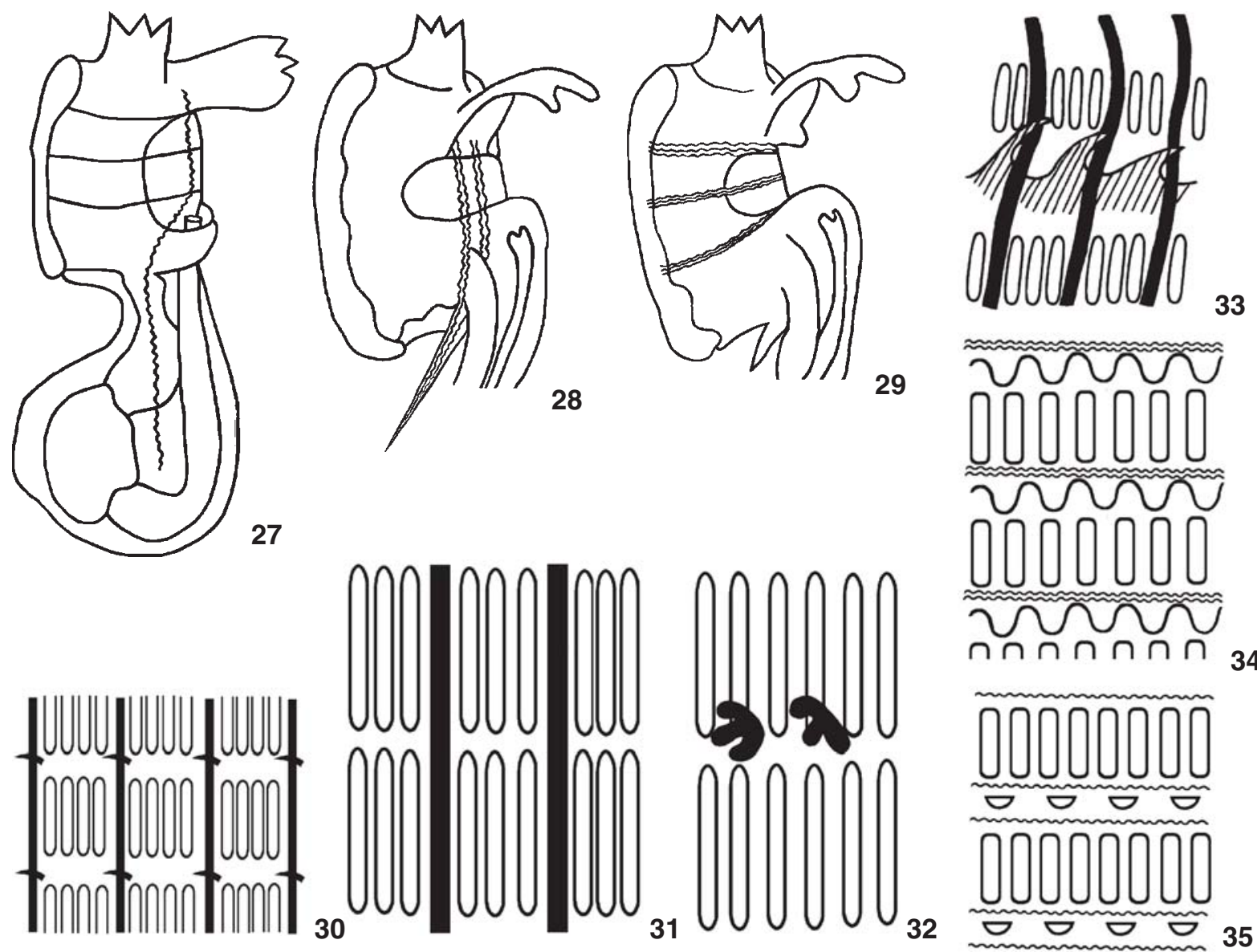

Figures 27-35. (27-29) Pharyngeal muscle: (27) dorsal longitudinal band extending until the abdomen; (28) dorsal longitudinal band originating the muscle process; (29) musculature on the pharyngeal transversal vessels; (30-32) pharyngeal longitudinal vessels: (30-31) complete; (32) incomplete; (33-35) pharyngeal papillae in: (33) Rhopalaea; (34) Polyclinum; (35) Monniotus.

clade Neodistoma (Distaplia+Hypsistozoa). This character is polymorphic in Molgula, Dumus, Monniotus and Hypsistozoa. The plesiomorphic state is "presence" (22.1) in Hypsistozoa, in comparison with the external functional group. Conversely, the plesiomorphic state for Monniotus and Dumus is "absent" (22.0).

Branchial papillae are not present (23.1) (Fig. 33) in Branchiostoma, neither in Pyura+Molgula or in Stomozoa+. Short and rounded branchial papillae (24.1) (Figs 34 and 35) are found in Monniotus+Protopolyclinum. This papillae type was also coded for Protopolyclinum, even though none of the species was directly studied, and will require confirmation (Millar 1960).

A simple prepharyngeal groove (25.1) appears in Branchiostoma and in the basal taxa of the ingroup. A double prepharyngeal groove (25.0) was derived many times independently in the taxa Ciona+, Ecteinascidia, Nephtheis, Exostoma and Polyclinum. Other genera present both states, e.g., Clavelina, Eudistoma and Aplidium.

The shape of the neural gland opening seems to be asso- ciated with the size of the organisms, but small and round neural gland opening (26.1) provides a supporting character for the clade Cionat.

The ancestral condition of the digestive tract is elongated with oral and anal extremities distant one from the other, as previously described in the discussion of body shape. A poorly differentiated elongated stomach (27.0) (Fig. 36) occurs in Branchiostoma and Ciona+ and it is also the plesiomorphic state. A short stomach then developed, becoming rectangular or barrel-shaped (27.1) (Figs 37-39), which occurs in most genera of the ingroup. Then other shapes arose: trapezoidal (27.3) (Fig. $41)$ as a synapomorphy for Brevicollus (Exostoma+Eudistoma); kidney-shaped (27.2) (Fig. 40) as a synapomorphy of Distaplia+ Hypsistozoa and rounded (27.4) (Fig. 42), first in Perophora and again in Diplosoma+. A reversion to state 27.0 occurred in Dumus. While the shape of the stomach is rather constant within the genus, the character "stomach wall" (28) (Figs 3643 ) is polymorphic for many of them (Ciona, Ascidia, Pyura, 


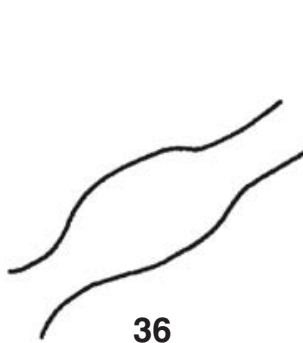

36

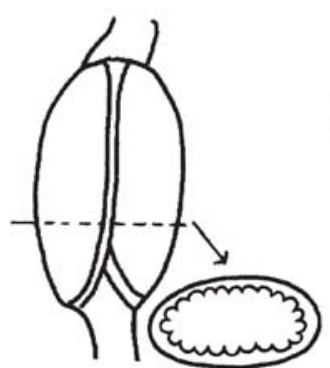

43
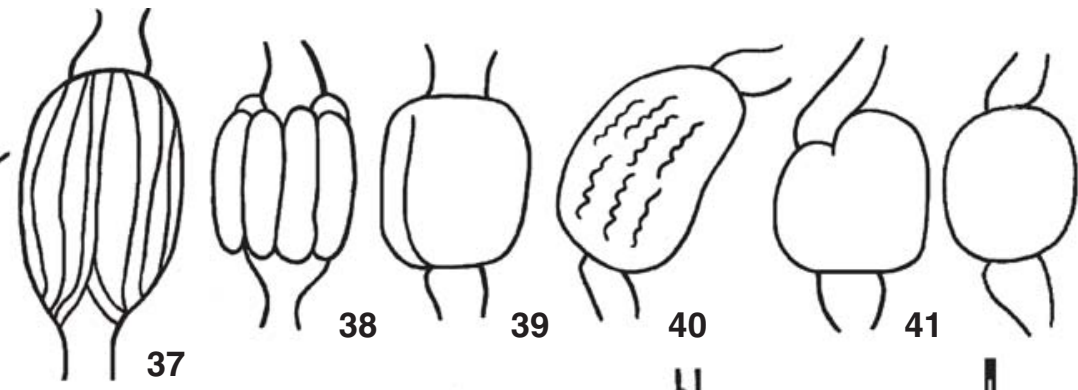

42

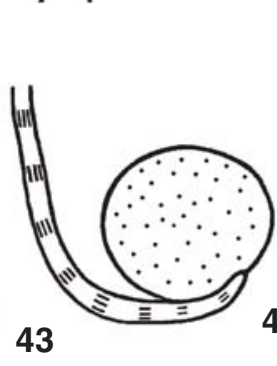

44
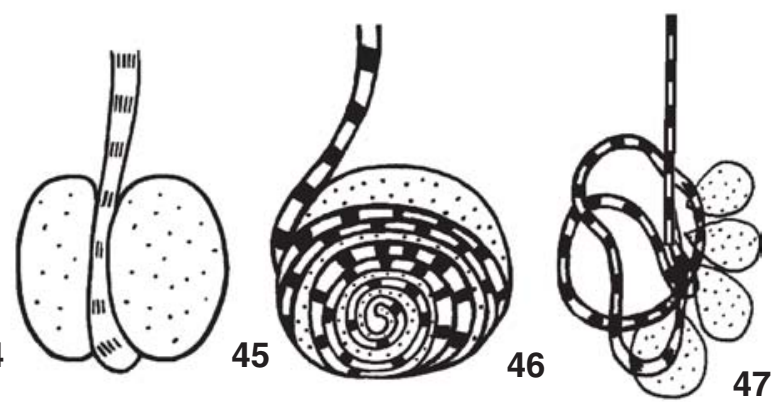

Figures 36-47. (36-43) Stomach shape: (36) elongated; (37) oval with folded wall; (38) square with longitudinal folds; (39) square and smooth; (40) kidney-shaped and ornamented; (41) trapezoidal and smooth; (42) rounded and smooth; (43) oval with internal folds; (44-47) proximal end of the spermiduct: (44-45) right; (46) spiraled; (47) convolute.

Ecteinascidia, Euclavella, Pseudodistoma, Dumus, Monniotus and Distaplia) what makes it difficult to interpret. The state (28.4) only appears in Dumus dumosus (Monniot, 1987) and Protopolyclinum pedunculatum (Millar, 1960).

The esophagus is short (29.0) in the taxa considered as out-group and in the more basal genera of the ingroup (plesiomorphic state). With elongation of the intestine in Stomozoa + the stomach moved to the posterior half of the abdomen (29.2). In Placentela crystallina+ the stomach is in the middle of the proximal branch of the gut (29.1). The middle position arises independently in Tylobranchion, Euclavella+ Nephtheis and in Brevicollus. Reversion to state (29.0) occurs in Polyclinum.

The most basal taxa with a posterior stomach (30.1) are (Perophora+Ecteinascidia) + , supporting their placement in the internal group. The posterior stomach disappears in the clade Clavelina (Euclavella+Nephtheis) and in Neodistoma (Hypsistozoa+ Distaplia). The gastric reservoir (31.1) is a synapomorphy for the Neodistoma(Distaplia+ Hypsistozoa) clade.

Gonads in the abdomen below the intestinal loop (32.1) arose twice, in Tylobranchion and Hypsistozoa. In Tylobranchion speciosum part of the gonads lies in the intestinal loop, the remainder extends to the posterior abdomen. Hypsistozoa has no posterior abdomen, but the gonads are located below the intestinal loop, in the proximal part of the vascular stolon. In both, the state of the character was coded "below intestinal loop" (32.1). Beginning with Anadistoma+ the gonads move posteriorly to the posterior abdomen (32.2). Reversion to gonads inside the intestinal loop (32.0) occurs in (Neodistoma (Distaplia+Hypsistozoa))+. A gonadal sac (32.3) was only ob- served in some species of Distaplia. However, by comparison with the outgroup Neodistoma, we concluded that the plesiomorphic state of this character is 32.0 for Distaplia.

The ovary in the center of the testis lobes (33.0) is the plesiomorphic condition. In Euherdmania + the ovary is anterior to the testis lobes (33.1). A reversion occurs in Hypsistozoa (33.0) and in two species of Distaplia. The plesiomorphic state for Polyclinum was 33.1.

Lobed testes (34.0) are found in Pyura+Molgula, while Ciona, Ascidia and Diazona have an irregular, ramified and elongated testis (34.1). The rounded or pyriform shape of the lobes (34.2) is found in all other taxa studied. Only Clavelina is polymorphic, with plesiomorphic state 34.2. All taxa have a straight sperm duct (Figs 44 and 45), with spiral proximal sperm duct (35.1) (Fig. 46) being a synapomorphy for (Polysyncraton, Didemnum (Trididemnum+)) while the convoluted duct (35.2) (Fig. 47) for Brevicollus. Most taxa studied have more than 10 testis follicles (36.0) and there is a tendency to decrease number towards the more apical groups. Genera with more than 10 follicles were often variable. Distaplia, for instance, has from 10-20 follicles while in Aplidium the variation is even greater: from 10 in A. lobatum Savigny, 1816 up to 58 in A. flavolineatum Monniot, 1987. That number also varies according to the state of maturation of the gonad. Polymorphisms occur in Perophora, Lissoclinum, Leptoclinides and Atriolum.

Numerous small oocytes (37.0) occur in Branchiostoma, Ciona+ and in the most basal taxa of the internal group. A reduction to less than 15 oocytes (37.1) begins with (Perophora+ Ecteinascidia)+. Only two reversions were observed, one in 
Clavelina and other in Placentela crystallina. The number of oocytes depends on the size of the ovary; the ovary becomes smaller when asexual reproduction is more developed.

The epicardium, while a difficult character to study in fixed specimens, is an important organ used as regenerative tissue in the reproductive process and formation of colonies in Aplousobranchia (except in Clavelinidae; BerRILl 1936, Котт 1990). In Ciona and other taxa of the internal group, the epicardium appears, just after the formation of the heart, as two evaginations of the pharynx (BerRILL 1936, 1950). Only in Ciona are these evaginations connected with the pharynx. In most other taxa, the epicardium sacs fuse and follow the abdomen - between the heart and the intestinal loop (in Diazona, Clavelina, Pycnoclavella, Polycitor and Eudistoma) - or the posterior abdomen (in Polyclinum and Aplidium) (BerRILL 1936). In Tylobranchion, the epicardium extends along the vascular stolon and continues towards the base of the colony (Котт 1969). In Placentela crystallina, the epicardium extends into the posterior abdomen (NishiKawa 1984), although the heart is not found there. As in Ciona, the epicardium sacs remain separate and do not connect to the pharynx in Euherdmania. Two reduced epicardium sacs are near the oesophageal stalk of the Didemnidae. Perophora retains no trace of the epicardium, neither in its original form nor in the form of a renal vesicle (BerRILL 1936).

Diazona and all the taxa of the internal group reproduce asexually. Characters for vegetative reproduction of most genera were obtained from the literature. Ciona is a solitary, sexual, ascidian that can regenerate the thoracic area and the epicardium is capable of regenerating all other tissues (Котт 1981). Rhopalaea crassa and R. neapolitana also do not bud, but occasionally the thorax degenerates, is absorbed and followed by the formation of a new thorax from the oesophageal region. This process is intermediate between regeneration and true budding through strobilization (Котт 1981). In Diazona, Polycitor (Котт 1990), Eudistoma (BerRill 1950), and possibly in Stomozoa (Kотт 1981) budding involves the epicardium and the alimentary canal. Buds form following thorax reabsorption and alimentary reserve accumulation in the abdomen; budding then occurs by strobilization or by epidermal transverse constrictions of the abdomen (38.0) (BERRILL 1950). In Anadistoma+ strobilization occurs in the epicardium sac within the posterior abdomen (38.1) (Berrill 1950, Millar 1966, Котt 1992). In Tylobranchion speciosum buds form by dissolution of the thorax and the abdomen, and by constriction of the posterior abdomen (38.1) (Berrill 1935). In Neodistoma, Distaplia and Hypsistozoa asexual reproduction occurs not in the vascular appendix, but rather by the extension of the epicardium in the vegetative stolon. Bud formation in Distaplia rosea Della Valle, 1881 occurs when mature zooids degenerate and the incubatory pouch is isolated and two small masses of tissue (originating in the anterior epicardium) develop near the oesophagus (BERRILL 1935). Highly specialized asexual reproduction occurs in Didemnidae (Diplosoma+) in which budding resembles that of Distaplia (BerRILl 1936). Buds are formed in the area of the oesophageal stalk, with reduced epicardium sacs. These types of budding were considered homologous (38.2). Clavelina and Perophora reproduce vegetatively without the involvement of epicardium sacs (38.3). In Clavelina, Nephtheis and Perophora, bud formation occurs in a large vascular stolon (Котт 1990); here the mesenchyme of the vascular septum is the principal regenerative tissue (KoTt 1981). BERRILL (1950) and TrASON (1963) suggested that Pycnoclavella reproduces by strobilization of the abdomen. Millar (1966) and Котт (1990) disagreed and proposed that budding in this taxon is through the vascular stolon as in Clavelina. Due to the divergence of information this character was classified as absent (?) in the data matrix.

External fertilization (39.0) occurs in Branchiostoma, Ciona+, Rhopalaea and Diazona (plesiomorphic state). In Tylobranchion, and all other taxa of the internal group, fertilization is internal (39.1), accompanied with the incubation of embryos. Internal fertilization appears along with viviparity and has some relationship with colonial life, although internal fertilization also appeared independently in Molgula. In Diazona, small oocytes leave the zooid before the fertilization and so this genus is considered oviparous (BerRILl 1950, Millar 1970, Котт 1990). We found no embryos in the specimens of Tylobranchion speciosum studied here, but BerRILl (1935) and Millar (1960) both speak of well-developed larvae incubated in the atrial cavity. A few taxa seem to only incubate larvae in the oviduct: Polycitor circes Michaelsen, 1930, Pycnoclavella, Monniotus and Euherdmania. Trason (1957) states that embryos of Euherdmania claviformis (Ritter, 1903) pass from the oviduct to the atrial cavity when mature. An incubation pouch (41.1) supports the clade (Hypsistozoa+Distaplia). Embryos were absent in all of our Synoicum specimens, while Kott (1969) describes the incubation of 1-8 embryos in isolated incubation pouches in the tunic of Synoicum adareanum (Herdman, 1902).

Most solitary ascidians do not incubate larvae, and so larval characters were included when available in literature. Ciona+ and Diazona produce simple and tiny larvae (maximum length of $0.2 \mathrm{~mm}$ ). The character state "small larvae" occurs mostly in solitary ascidians and is associated with oviparity. The larval complexity the appeared in the taxa of Aplousobranchia does not occur in the larvae of oviparous species nor in the colonial or solitary viviparous forms of Stolidobranchia. Diazona, despite being colonial, is oviparous (BerRILl 1950, Millar 1970, KotT 1990) and the larvae are similar to those of Ciona+. No information on larvae from Rhopalaea was available. In the remaining ingroup taxa, larvae are larger than $0.4 \mathrm{~mm}$ (42.1). Tylobranchion, the most basal taxon of the internal group to present viviparity produces embryos that reach $0.55 \mathrm{~mm}$ (Millar 1960, 1971) while some genera (e.g., Stomozoa, Synoicum, Distaplia and Leptoclinides) produce even larger embryos (> $1.7 \mathrm{~mm})$.

While ectodermal ampullae (Figs 48 and 49) are usually not visible in the larvae of solitary ascidians, in colonial ascidians ampullae are frequently conspicuous processes behind the 
adhesive papillae being digitiform, capitate, bulbous, or clavate. They grow from the epidermis of the trunk soon after larval fixation, with subsequent retraction (CLONEY 1982), thus they are secondary organs of fixation with glandular cells that produce adhesive compounds. Only some species of Pycnoclavella (P. minuta Millar, 1953b and P. stanleyi Berrill \& Abbott, 1949) have ectodermal ampullae. Distaplia, Pseudodistoma and Stomozoa were polymorphic for this character. The plesiomorphic states, by comparison with functional outgroups, were 43.0 for Pycnoclavella and Pseudodistoma, and 43.1 for Distaplia. The presence of ectodermal ampullae (43.1) supports the clade P. crystallinus Renier, 1804 (Brevicollus (Exostoma+Eudistoma)) and the clade Ritterella+. Independent origin for ectodermal ampullae occurs in larvae of Ecteinascidia.

Adhesive papillae (44) appeared in the ancestral of ascidians with a loss in larvae of Molgulidae which have no adhesive papillae, but the epidermis of the trunk secretes adhesive compounds serving the same function. While in many colonial ascidians, papillae evert quickly and expose the adhesive compounds, in solitary ascidians and some colonial ones (e.g., Clavelina) papillae do not evert but rather simply secrete adhesives (Cloney 1982). Non-everting, conical adhesive papillae (44.0) (Fig. 50) are present in Ciona+, Diazona and Tylobranchion. Everting adhesive papillae (44.1) (Figs 48-50) appear in (Perophora+Ecteinascidia)+, and only reverting in Clavelina. Everting papillae in Perophora (Stach \& Turbeville 2002) reinforces its position in internal group. This character was not polymorphic in any genus.

The linear row of adhesive papillae (45.1) (Figs 48 and 49) appeared independently two times in the internal group: in Perophora+Ecteinascidia, and in the clade beginning with (Polycitor crystallinus (Brevicollus(Exostoma+Eudistoma)))+. Reversion to the state 45.0 occurs only in Distaplia+Hypsistozoa. Although modified several times in the internal group, papillar arrangement is very fixed within each genus. Most species included in this analysis have three adhesive papillae, but the studied species of Euherdmania all had two adhesive papillae (invaginated tubes), as well as two species of Pycnoclavella, which have the invaginated type. Since the type species for Pycnoclavella (P. aurilucens Garstang, 1891) and P. stanley have three papillae, this was considered the plesiomorphic state of this character. The reduction to two adhesive papillae in the larva clearly occurred independently in Euherdmania and Pycnoclavella. Sessile papillae (46.0) (Fig. 48) are found in the most basal taxa of the internal group. The stalk in the adhesive papillae (46.1) (Fig. 49) appeared in (Polycitor circes (Pycnoclavella (Clavelina (Nephtheis + Euclavella))) $)+$ and while present in most other taxa in the internal group, reversions occurred in Brevicollus and Pseudodistoma. In Clavelina, adhesive papillae do not present stalks, however they are supported by a peduncular process (46.2) (Fig. 50). This character was only polymorphic in Distaplia, and the plesiomorphic state defined was 46.1.

Vesicles in the larval trunk (47.1) appeared independently in Brevicollus and in the clade (Dumus(Monniotus+Protopoly- clinum))+, and were lost in the clade (Neodistoma (Distaplia+ Hypsistozoa))+Diplosoma+. Another reversion occurred in Protopolyclinum. Only Aplidium was polymorphic for this character, and the plesiomorphic state was defined as 47.1. Vesicles in the trunk of Aplidium are derived from evaginations such as the ampullae (Cloney 1982).

\section{Phylogenetic reconstruction}

Aplousobranchia sensu Lahille (Stomozoa+) is a monophyletic group supported by the following characters: loss of internal longitudinal pharyngeal vessels (21.2) and of the branchial papillae (23.1), and the stomach in the posterior half of the proximal branch of the gut (29.2). However, Aplousobranchia sensu Котт $(1969,1990)$ is not monophyletic since, in our analysis, ascidians divided into two branches with Ciona in the base of one branch and the other "Aplousobranchia" in the other branch that includes Perophora+Ecteinascidia. Also the position of Diazona and Rhopalaea is not resolved, appearing either in each of the branches. Ciona, Perophora, Ecteinascidia, Rhopalaea, Diazona and Tylobranchion have been traditionally considered genera of Phlebobranchia Lahille and not of Aplousobranchia (VAN NAME 1945, Millar 1966, Tokioka 1967, Monniot \& Monniot 1972). The inclusion of some of these genera in Aplousobranchia was proposed by Котт $(1969,1990)$ and supported by the same oxidation state of vanadium (IV) in Ciona, Rhopalaea, Diazona and Tylobranchion and in the taxa of Aplousobranchia (Hawkins et al. 1983). The position of Cionidae in the base of the other branch suggests that the oxidation state IV of vanadium is the plesiomorphic state. Recent molecular analysis based on partial COI sequences also suggests a close position between Ciona and the Aplousobranchia as sister-groups (Turon \& López-LegenTIL 2004). These cladograms also included Diazonidae within Aplousobranchia. Therefore, even though Ciona is usually considered a very basal genus within Ascidiacea, its position is still debatable.

Tylobranchion, and Perophora+Ecteinascidia are basal groups and comprise, together with Aplousobranchia sensu Lahille, a natural group, supported by the following characters: colonial life habit (1.1), less than 30 longitudinal thoracic muscle bands (13.1), internal fertilization (39.1) with incubation of embryos (40.1) and length of the larval trunk greater than $0.4 \mathrm{~mm}(42.1)$.

The position of Ecteinascidia+Perophora remains debatable. Here, characters 1.1 (colonialism), 13.1 (few longitudinal muscle bands), 20.1 (up to 30 rows of stigmata), 30.1 (posterior stomach present), 37.1 (few oocytes), 39.1 (internal fertilization), 40.1 (incubation of embryos), 42.1 (large larval trunk) and 44.1 (everting adhesive papillae in the larva), placed these groups within the internal group. The alignment of the adhesive papillae of the larvae in a row (45.1) is also a character that occurs only within Aplousobranchia. On the other hand, molecular data, both from 18S rDNA sequences (STACH \& Turbeville 2002) and partial COI sequences (Turon \& López-Legentil 2004) placed 




48

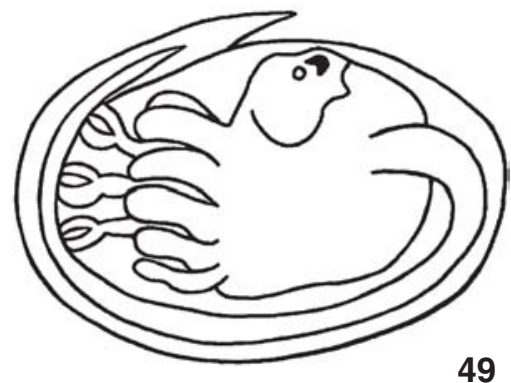

49

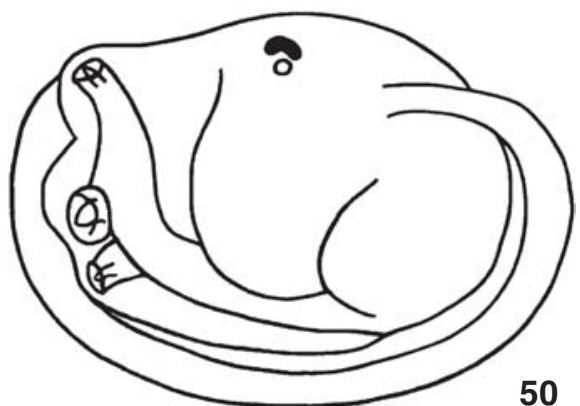

50

Figure 48-50. Larval adhesive papillae. (48) sessile in a linear arrangement, (49) stalked in linear arrangement, (50) on a peduncular process, in triangle.

Perophoridae close to Ascidiidae outside the Aplousobranchia.

Even though Phlebobranchia was not part of this study and few genera were included in the analysis, the results suggest paraphyly for this taxon. Molecular analysis also showed different results with this respect: the analysis with COI did not confirm the Phlebobranchia clade (Turon \& López-LegentiL 2004) while $18 \mathrm{~S}$ rRNA analysis indicated monophyly for this taxon (Stach \& Turbeville 2002).

Our results also indicate paraphyly for the order Enterogona since genera of Phlebobranchia and Aplousobranchia are split into different branches. Nor did analysis based on COI confirm the clade Enterogona (Turon \& López-Legentil 2004). This clade apparently was defined on the basis of many plesiomorphic characters either shared by cephalochordates (pharynx not folded with longitudinal vessels) or not (gonads associated with the intestinal tract). Further research with the other genera of Phlebobranchia will be necessary in support of clarifying the evolution of the Ascidiacea.

\section{Evolutionary trends}

Colonialism seems to have appeared early in the evolutionary history of Aplousobranchia. Evolution proceeded in the direction of smaller zooids and simplification of the pharynx. The change from solitary to colonial is closely associated with the increase in regenerative ability and the consequent emergence of asexual reproduction. Interruption of individual growth due to a growing investment in asexual reproduction is suggested as the reason for the decrease in zooid size and consequent reduction of structures, especially of the pharynx (Котт 1969).

Although a clear trend towards pharynx simplification occurred, this trend is not clearly correlated with reduction in pharynx size, at least in the basal genera. In these genera, there are large species with or without longitudinal vessels (eg. Clavelina without, Diazona with), small species with longitudinal vessels (eg. Perophora). The large thorax of Tylobranchion speciosum has incomplete vessels while some small Perophora present complete vessels. A complete loss of longitudinal vessels occurred in Stomozoa+. While not previously mentioned for most taxa, muscles on the transverse vessels of the phar- ynx, present in most derived genera support the clade Ritterella+, which includes genera from the traditional family Polyclinidae, the Holozoidae (Neodistoma(Distaplia+Hypsistozoa) and Didemnidae (Diplosoma+). The dorsal pharyngeal muscle band supports the relationship among the Holozoidae and Didemnidae and its presence seems to be associated with the modification of the atrial siphon into a wide opening directed to the cloacal channels.

All of the characters associated with the pharynx (vessels, papillae, and transverse muscle) seem to have greater phylogenetic value than body division and the position of the heart, gonads and epicardium in the evolution of Aplousobranchia. Dividing the body into two (thorax and abdomen) or three (thorax, abdomen and posterior abdomen) regions was classically proposed as a major driving force in the evolution of Aplousobranchia, reflected in its classification (VAN NAME 1945, Millar 1966, Monniot \& Monniot 1972). In contrast, our analysis shows that Tylobranchion, despite its posterior abdomen, is located more basally and distant from the other species with a posterior abdomen (traditional family Polyclinidae). After a second appearance of the posterior abdomen in Anadistoma+ it was lost again in (Neodistoma(Distaplia+Hypsistozoa))+Diplosoma+.

Characters associated with the musculature of the body wall, not often used to establish relationships among ascidian groups, were phylogenetically useful. The transverse musculature is restricted to some taxa and supported the clade Dumus(Monniotus+ Protopolyclinum).

Asexual reproduction triggered the development of colonial systems through different budding mechanisms and apparently colonialism arose only once within Aplousobranchia. WADA et al. (1992) stated that asexual reproduction arose many times and independently in Phlebobranchia and Stolidobranchia. However, if the genera Perophora, Ecteinascidia and Diazona are included in Aplousobranchia then asexual reproduction never appeared in Phlebobranchia.

Another evolutionary trend associated with colonial species was the formation of systems, culminating with the organization of specialized cloacal systems in (Synoicum+ Polyclinum)+. No reversion to the absence of a cloacal system ever occurred. 
Again, cloacal systems are present both in species with and without a posterior abdomen, showing that a posterior abdomen is not a valid character for the classification of Aplousobranchia. Associated with the development of the cloacal systems there was a change of the atrial siphon aperture. While in (Synoicum+ Polyclinum + Aplidium + the atrial aperture is small, it becomes a wide opening in ascidians with developed cloacal systems, such as in the clade (Neodistoma(Distaplia+Hypsistozoa))+, although it appears as a tubular siphon in some genera of this last clade: Trididemum(Leptoclinides+Atriolum).

Trends associated with the evolution of the larva itself included the change from simple and small larvae, with three conical adhesive papillae in triangle, without ectodermal ampullae or vesicles (Tylobranchion or maybe Diazona) to larger and quite complex larvae, with everting adhesive papillae of different types in a stalk extremity, ectodermal ampullae and sometimes vesicles. Adhesive papillae in a linear row appeared twice, in Perophora+Ecteinascidia, and supporting the clade (Polycitor crystallinus(Brevicollus (Eudistoma+Exostoma)))+, with reversion only in Neodistoma(Distaplia+Hypsistozoa). The complexity of the larvae produced by Aplousobranchia taxa is not found in larvae of oviparous ascidians nor in either colonial or solitary viviparous forms of Stolidobranchia.

Most solitary forms release gametes into the water, where fertilization and development occur. Thence, colonial ascidians became viviparous, producing large eggs in smaller numbers. Rhopalaea and Diazona do not incubate larvae and produce many oocytes. When more basal taxa are viviparous they incubate a greater number of embryos relative to the more derived taxa. For example, Tylobranchion speciosum, Clavelina oblonga and Placentela crystallina each incubate more than 20 embryos in the atrial cavity. The increase in larval size is also a trend (Millar 1971) in which small larvae (trunk $<0.30 \mathrm{~mm}$ ) are usually from solitary ascidians, while the largest sizes are from colonial species (trunk $>0.5 \mathrm{~mm}$ ). Some are quite large, such as Polycitor circes and Hypsistozoa fasmeriana Michaelsen, 1924, with trunks of $2.5 \mathrm{~mm}$.

Embryo protection developed in a variety of ways: retention within the oviduct, within the atrial cavity, within an incubating pouch, or within the tunic of the colony (MILLAR 1971). Basal taxa of the internal group - with large zooids - incubate larvae within the atrial cavity or oviduct. However, in smaller individuals with relatively large larvae (e.g., Distaplia+ Hypsistozoa), the brood pouches projects from the body wall. Also, the atrial opening is quite wide in Neodistoma + with little space within the atrial cavity for incubation. Diplosoma + are also tiny (average $1 \mathrm{~mm}$ ) and large larvae are incubated within the tunic, completely independent of the zooid. The most elaborate incubation yet discovered occurs in Hypsistozoa fasmeriana, in which the ovary produces a single small egg that grows into a large larva within the incubating pouch, where it receives nourishment through a pair of endodermal tubes. The embryo is incubated over a long time period, resulting in a quite complex larva with many blastozooids (BREWIN 1956).
Larvae leave the colony depending upon where they are incubated. In species that retain embryos in the atrial cavity, larvae escape directly through the atrial siphon or the common cloacal cavity. In Distaplia, the zooid dies upon separation from incubating pouch and the larvae are liberated then when the tunic dissolves (BERRILL 1948). A similar process occurs in Synoicum adareanum (Kott, 1969). In ascidians with small zooids, one only embryo usually grows and it is liberated by rupture of the body wall. In Diplosoma+ extreme specialization occurs in this direction: eggs pass directly from the abdomen to the tunic of the colony, where they are fertilized and grow (Millar 1971).

\section{Monophyly of the families within Aplousobranchia}

Considering the three traditional families of the order (Van Name 1945, Millar 1966, Monniot \& Monniot 1972), only Didemnidae is a natural group, and clearly Polyclinidae and Polycitoridae are not monophyletic (Figs 1 and 51). Ciona appeared in the resulting cladogram as a more basal taxon of the branch Ciona (Ascidia(Pyura+Molgula)) out of Aplousobranchia, supporting the valid family Cionidae. Cionidae Lahille, 1887 is considered monogeneric by several authors (VAN NAME 1945, Berrill 1950, Kott 1990). Monniot \& Monniot (1972), however, included Rhopalaea, Diazona, Tylobranchion, Pseudodiazona Millar, 1963a, Ciallusia Van Name, 1918, Pterygascidia Sluiter, 1904, Rhopalopsis Herdman, 1880, Corellopsis Millar, 1970 and Syndiazona Oka, 1926 as genera within the Cionidae. Our results indicate that the first three genera belong to other families (the last six genera were not included in this analysis).

Diazonidae Garstang, 1891 traditionally includes the genera Diazona, Rhopalaea, Tylobranchion, Pseudodiazona and Syndiazona Oka, 1926. Here, Rhopalaea, Diazona and Tylobranchion (T. speciosum) did not group together, and Tylobranchionidae fam. nov. was created to include Tylobranchion. Rhopalaea and Diazona grouped together in some trees but not in others, thereby further study is required to resolve the position of these and the other genera.

Here, Perophoridae Giard, 1872 including the genera Perophora and Ecteinascidia was considered valid and well supported by characters intestinal loop and gonads lateral to the pharynx, body undivided, sac like, colony with stolonic form, longitudinal thoracic muscle bands oblique in relation to the endostyle, asexual reproduction by budding of the vascular appendix or vascular stolon and a linear arrangement of adhesive papillae.

The traditional family Polycitoridae is not a monophyletic group. Котт (1990) proposed the inclusion of Clavelina+ Nephtheis in Clavelinidae Forbes \& Hanley, 1848 and created Pycnoclavellidae Kott, 1990 for the genera Euclavella+ Pycnoclavella. Clavelinidae was characterized by its exclusive form of budding in the terminal portion of the stolonic vase, not involving the epicardium (BERRILL 1936, 1950), the plain margin of the siphon, the many small eggs, the larvae with papil- 


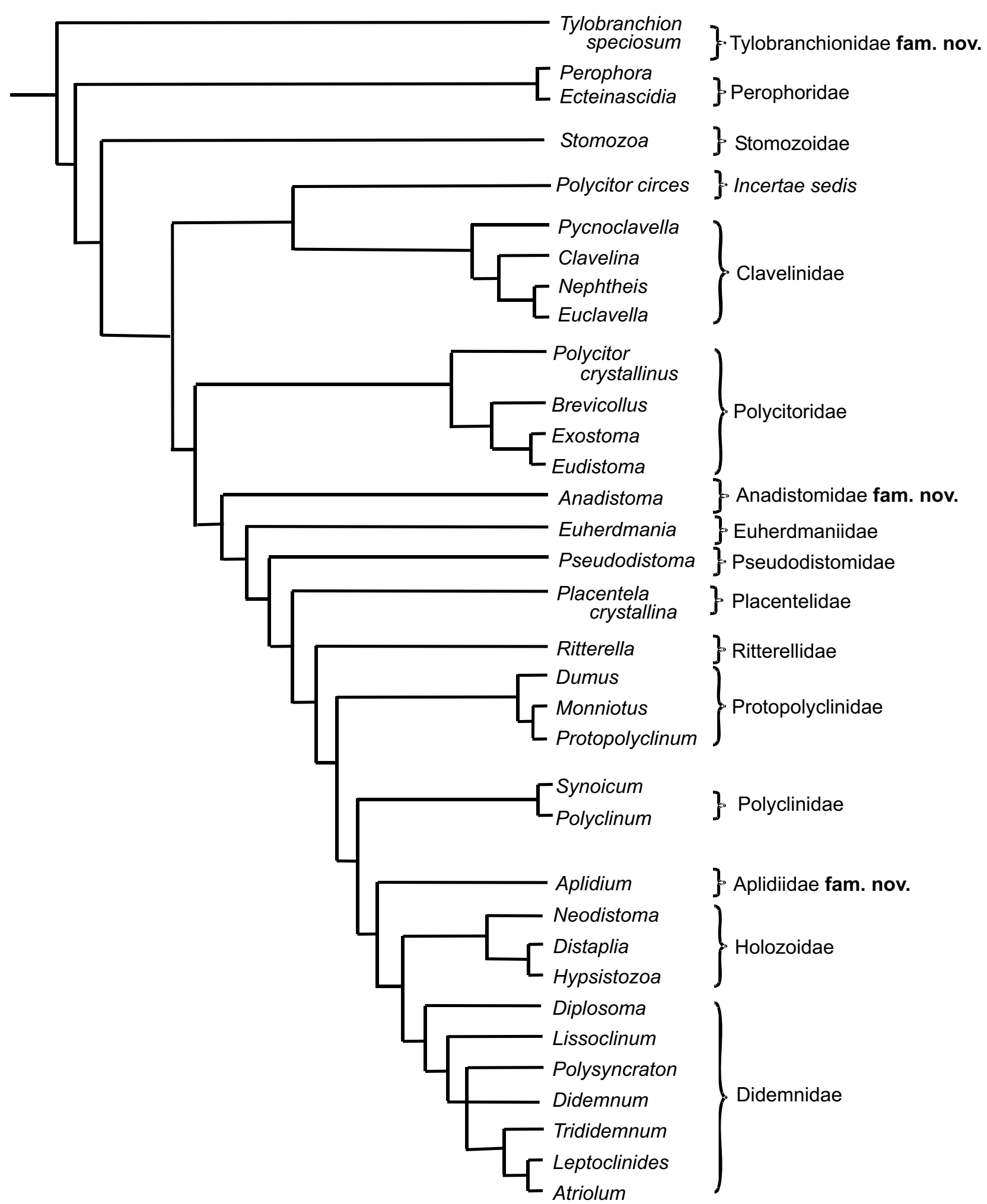

Figure 51. Cladogram indicating the clades which are monophyletic and belong to the category "Family". 
lae in triangle and the absence of an epidermal calyx (Котт 1969). In this work, the four genera form a monophyletic group, Pycnoclavella(Clavelina(Euclavella+Nephtheis)), supported only by the characters oral siphon with flat margin and asexual reproduction by budding of the vascular appendix or vascular stolon, and represent Clavelinidae Forbes \& Hanley, 1848. Clavelina(Euclavella+Nephtheis) is supported by character without posterior stomach. In partial COI sequences, Clavelina, Pycnoclavella and Archidistoma appeared together as a monophyletic group with strong support in all trees retrieved by Turon \& López-Legentil (2004), thereby confirming our results. Stomozoa appears as an isolated branch in the cladogram (Figs 1 and 51) at the base of the clade (Polycitor circes(Pycnoclavella(Clavelina(Euclavella+Nephtheis))))+. Therefore we follow the proposal of Котт (1990), and put Stomozoa as the only genus in Stomozoidae Kott, 1990.

The clade Exostoma+Eudistoma was supported by character three rows of stigmata, while the clade Brevicollus(Exostoma+ Eudistoma) was supported by characters colony in form of cushion and trapezoidal shape of the stomach. Polycitor crystallinus(Brevicollus(Exostoma+Eudistoma)) also form a monophyletic group supported by the character presence of ectodermal ampullae in the larva. Котт (1990) included these four genera, together with Archidistoma Garstang, 1891, Polycitorella Michaelsen, 1924 and Cystodytes Drasche, 1883 in Polycitoridae Michaelsen, 1904, which remained valid here.

Polycitor, however, is apparently not monophyletic. Polycitor circes appears at the base of the clade (Pycnoclavella (Clavelina(Euclavella+Nephtheis))) (Figs 1 and 51), separated from $P$. crystallinus due to the lack of a transverse thoracic muscle in the body wall and the triangular arrangement of the adhesive papillae of the larvae. Polycitor crystallinus has many primitive characters (Котт 1969) that indicate a greater proximity with Diazona when compared to the other species of the genus. Here, however, $P$. circes is distant from Diazona in the cladogram.

Anadistoma is the most basal genus of the clade comprising ascidians with a posterior abdomen (old family Polyclinidae) that share characters associated with the elongation of the body, as the elongation of the longitudinal muscle to the base of the posterior abdomen, gonads in posterior abdomen and asexual reproduction by strobilization of this part of the body. We propose the new family, Anadistomidae fam. nov., to include this genus (Figs 1 and 51).

Котт (1992) proposed Euherdmaniidae Ritter, 1904 for Euherdmania, which appears as an isolated branch and is supported here. Euherdmania differs from Pseudodistoma by transverse muscle in the body wall, by the largest number of rows of stigmata, and only two, invaginated, adhesive papillae in the larva.

Котт (1992) proposed Pseudodistomidae Kott, 1992 to include Pseudodistoma, Anadistoma and Citorclinum Monniot \& Millar, 1988, which we consider valid, but with only Pseudodistoma. Pseudodistoma appears as an isolated branch, with char- acters absence of transverse thoracic muscle in the body wall and two autapomorphies: three rows of pharyngeal stigmata and stalk absent in the adhesive papillae of the larva. Further studies are needed to define the position of Citorclinum in Pseudodistomidae or in Anadistomidae.

Genera belonging to the clade beginning with Placentela crystallina differ from Anadistoma, Euherdmania and Pseudodistoma by having siphons with pointed lobes and the stomach in the middle of the proximal branch of the alimentary canal. Euherdmania and Pseudodistoma do not have muscle bands on the transverse vessels of the pharynx as occurs in the clade Ritterella+. Kотт (1992) proposed Placentelidae Kott, 1992 to include Placentela, which we maintain.

The genera Ritterella and Dumus comprise Ritterellidae Kott, 1992. In our cladograms, however, Ritterella is placed in a separate taxon at the base of the clade Ritterella+, and supported by the characters presence of transverse pharyngeal muscle and ectodermal ampullae in the larva. Thus, we propose that Ritterella only is considered into Ritterellidae. Dumus is a sister-group to Monniotus+Protopolyclinum, forming Protopolyclinidae Kott, 1992 supported by the characters presence of transverse muscles on the body wall and digitiform projections in an encrusting colony with an expanded base). Котт (1992) also included Condominium in this family, but our analysis could not confirm this due to the lack of larval information in Condominium. Systems without true or rudimentary cloacal cavity, siphons with pointed lobes, presence of muscle on transverse vessels of the pharynx and short oesophageal stalk indicates a probable position of Condominium among the genera of the clade beginning with Ritterella, possibly as a basal taxon in the clade Dumus (Monniotus+Protopolyclinum). However, branchial papillae are lacking, yet present in Monniotus+Protopolyclinum.

Polyclinidae Milne-Edwards, 1841 sensu Котт (1992) is not monophyletic since only Synoicum+Polyclinum form a clade and Aplidium is in an isolated branch in the cladogram. We considered the genera Synoicum and Polyclinum in Polyclinidae Milne-Edwards, 1841 and Aplidium to Aplidiidae fam. nov. Polyclinidae should also include the genera Aplidiopsis Lahille, 1890, Sidneioides Kesteven, 1909 and Morchellium Giard, 1872 (Котт 1992).

The clade Neodistoma(Distaplia+Hypsistozoa) appears in all the cladograms and is supported by four characters (Figs 1 and 51) which concur with the inclusion of these genera within Holozoidae as did Котт (1990). Other genera, included in this family are: Sigillina Savigny, 1816, Polydistoma Kott, 1990, Нypodistoma Tokioka, 1967, Sycozoa Lesson, 1830 and Protoholozoa Kott, 1969, but none of those were included in this analysis.

The monophyly of Didemnidae Giard, 1872 (Diplosoma+) is supported by five characters: sheet-like colony, muscle process present, rounded, smooth stomach and larvae incubated in the tunic (Figs 1 and 51). In addition to the seven genera included in this analysis, several other genera are included in the family (i.e., Botrydemnum Oka, 1933, Clitella Kott, 2001, 
Coelocormus Herdman, 1886, Didemnopsis Hartmeyer, 1903 and Sinecloaca Michaelsen, 1930). BERRILL (1936) suggested a common ancestry for Didemnidae and Holozoinae, while Котт (1992) proposed that similarities between Holozoinae and Didemnidae would be better explained by the independent reduction of zooid size, with subsequent parallel development. Here we confirm the proposal of Berrill (1936) in that the clade Holozoidae+Didemnidae was supported by nine characters, referring to modifications in the atrial siphon in function of cloacal systems, number of rows of stigmata, loss of the posterior abdomen, incubation type, absence of the vesicles in the larva and similarity in asexual reproduction (Fig. 1). The intestinal loop and heart of the Didemnidae are also similar to Distaplia (BerRILL 1936). More recently, HiRose (2001) described bladder cells in the tunic of Holozoidae and Didemnidae; these, however, are also found in Diazonidae and Ascidiidae. Molecular analysis (COI) gave different conclusions, with Didemnidae in a more basal position together with Cionidae (Turon \& López-Legentil 2004).

\section{Classification}

We recommend a classification based on our hypothesis of phylogenetic reconstruction (Figs 1 and 51). Here, one of the criteria was to minimize modifications of the existing classification. The sequence of the list of taxa follows the sequence of the branches in the cladogram (sequential system), because this system allows the classification of large groups using a relatively few categories, hence, the number of redundant names is relatively small and many names and categories of traditional classifications can be conserved (АмоRIM 1997). The terminal taxa referring to species (generated by problems in the definition of genera), appear in the classification as incertae sedis (WILEY et al. 1991) (Figs 1 and 51).

Enterogona Perrier, 1898

Aplousobranchia Lahille, 1887

Tylobranchionidae fam. nov.

Tylobranchion Herdman, 1886 (T. speciosum Herdman, 1886)

Perophoridae Giard, 1872

Perophora Wiegmann, 1835; Ecteinascidia Herdman, 1880

Stomozoidae Kott, 1990

Stomozoa Kott, 1957

Polycitor circes Michaelsen, 1930 incertae sedis

Clavelinidae Forbes \& Hanley, 1848

Pycnoclavella Garstang, 1891; Clavelina Savigny, 1816; Euclavella Kott, 1990; Nephtheis (Drasche, 1882)

Polycitoridae Michaelsen, 1904

Polycitor Renier, 1804 (P. crystallinus Renier, 1804); Brevicollus Kott, 1990; Exostoma Kott, 1990; Eudistoma Caullery, 1909

Anadistomidae fam. nov.

Anadistoma Kott, 1992

Euherdmaniidae Ritter, 1904
Euherdmania (Ritter, 1903)

Pseudodistomidae Kott, 1992

Pseudodistoma Michaelsen, 1924

Placentelidae Kott, 1992

Placentela Redikorzev, 1913 (P. crystallina Redikorzev, 1913)

Ritterellidae Kott, 1992

Ritterella Harant, 1931

Protopolyclinidae Kott, 1992

Dumus Brewin, 1952; Monniotus Millar, 1988; Protopolyclinum Millar, 1960

Polyclinidae Milne-Edwards, 1841

Polyclinum Savigny, 1816; Synoicum Phipps, 1774

Aplidiidae fam. nov.

Aplidium Savigny, 1816

Holozoidae Berrill, 1950

Neodistoma Kott, 1990; Distaplia Della Valle, 1881; Hypsistozoa Brewin, 1953

Didemnidae Giard, 1872

Diplosoma MacDonald, 1859; Lissoclinum Verrill, 1871; Polysyncranton Nott, 1892; Didemnum Savigny, 1816; Trididemnum Della Valle, 1881; Leptoclinides Bjerkan, 1905; Atriolum Kott, 1983

\section{ACKNOWLEDGEMENTS}

We especially thank the following researchers and institutions that lent study material: Françoise Monniot of the Museum National d'Histoire Naturelle de Paris; Linda Cole of the National Museum of Natural History - Smithsonian Institution, Washington, D.C.; Xavier Turon, from University of Barcelona, Spain; Shirley Parker-Nance from South Africa; Tito M. da C. Lotufo and Maurício Cobianch from Brazil; and Elsa Vázquez, from Spain, who donated material. Walter A.P. Boeger, Sérgio de A. Rodrigues, Antonio C. Marques, Luciane Marinoni, Gabriel A.R. de Melo and Thomas Stach all spent many hours reading and offering suggestions to improve the research and the manuscript, for which we are very grateful. We thank the Graduate Program in the Department of Zoology for logistic support, CNPq for the doctoral fellowship and CAPES for the doctoral-sandwich fellowship that allowed the first author to work at the Smithsonian Institution. Thanks to James J. Roper for suggestions to improve the English and the manuscript.

\section{LITERATURE CITED}

Amorim, D.S. 1997. Elementos básicos de Sistemática Filogenética. Ribeirão Preto, Holos, $2^{\mathrm{a}}$ ed., 276p.

Berrill, N.J. 1935. Studies in tunicate development. Part IV asexual reproduction. Royal Society of London Publications 526 B: 327-379.

Berrill, N.J. 1936. Studies in tunicate development. Part V the evolution and classification of ascidians. Royal Society of London Publication 530 B: 43-70.

Revista Brasileira de Zoologia 25 (2): 269-298, June, 2008 
Berrill, N.J. 1948. Budding and the reproductive cycle of Distaplia. Quarterly Journal of Microscopical Science 89: 253-289.

Berrill, N.J. 1950. The Tunicata - with an account of the British species. London, Ray Society, 354p.

BerRiLl, N.J. \& D.P. Аввотт 1949. The structure of the ascidian Pycnoclavella stanleyi sp. nov., and the nature of its tadpole larva. Canadian Journal of Research 27: 43-49.

BJerkan, P. 1905. Ascidien von dem norwegischen Fischereidampfer Michael Sars in den Jahren 1900-1904 gesammelt. Bergens Museum Arbog Afhandlingar og Arsberetning 1905 5: 4-29.

Brewin, I.B. 1952. Ascidians of New Zealand. Part VII - Ascidians of Otago coastal waters. Transactions and Proceedings of the Royal Society of New Zealand 79: 452-458.

BREWIN, I.B. 1953. Australian ascidians of the sub-family Holozoinae and a review of the sub-family. Transactions and Proceedings of the Royal Society of New Zealand 81 (1): 53-64.

BREWIN, I.B. 1956. The growth and development of a viviparous compound ascidian Hypsistozoa fasmeriana. Quarterly Journal of Microscopical Science 97: 435-454.

Cameron, C.B.; J.R Garey \& B.J.Swalla. 2000. Evolution in the chordate body plan: new insights from phylogenetic analysis of deuterostome phyla. Proceedings of the National Academy of Science USA 97: 4469-4474.

CAullerY, M. 1909. Récherches sur la famille des Distomidae. Bulletin Scientifique de la France et de la Belgique 42: 159.

Cloney, R.A. 1982. Ascidian larvae and the events of metamorphosis. American Zoologist 22: 817-826.

Della Valle, A. 1881. Nouve contribuzioni alla storia naturalle della ascidie composte del Golfo di Napoli. Atti della Reale Accademia dei Lincei, Series 3, Memoir 10 (3): 431-498.

Drasche, R. Von. 1882. Oxycorynia, eine neue SynascidienGattung. Verhandlugngen der Zoologisch Botanischen Gesellschaft Wien Österreich 32: 175-178.

Drasche, R. Von. 1883. Die Synascidien der Bucht von Rovigno (Istrien). In: Ein Beitrag zur Fauna der Adria (Wien), 41p.

Drasche, R. Von. 1884. Ueber einige neue und weniger gekannte aussereuropäische einfache Ascidien. Denkschriften. Akademie Wissenschaftlichen 48: 369-387.

Frtch, W.M. 1971. Toward defining the couse of evolution: minimum change for a specific tree topology. Systematic Zoology 20: 406-416.

Fleming, J. 1822. The Philosophy of Zoology. Edinburgh and London, vol. 2, p. 508-518.

Forbes \& S.C.T. Hanley. 1848. A History of British molluscs and their shells. London, vols 1,2 and 4.

GaILl, F. 1972. Répartition du genre Pseudodistoma (Tuniciers): description de deux espéces nouvelles. Cahiers de Biologie Marine 13: 3747.

GaRstang, W. 1891. Report on the tunicata of Plymouth. Journal of the Marine Biological Association, New Series 2: 4767.

Giard, A.M. 1872. Recherches sur les ascidies composées ou synascidies. Archives de Zoologie Experiméntale et Générale 1: 501-704.

Harant, H. 1930. Liste des Ascidies de Banyuls. Archives de Zoologie Experiméntale et Générale 70 (1): 15-22.

HaRANT, H. 1931. Contribution à l'histoire naturelle des ascidies et leurs parasites. Annales de l'Institut Océanographique Monaco 8 (4): 229-389.

Hartmeyer, R. 1903. Die ascidien der Arktis. Fauna Arctica 3 (2): 93-412.

Hartmeyer, R. 1911. Die ascidien der Deutschen SüdpolarExpedition 1901-1903. Deutschen Südpolar-Expedition (1905-31) 12 (4): 407-606.

Hartmeyer, R. 1913. Tunicata, p. 125-144. In: K. Schultze (Ed.). Zoologie und Anthropologie Ergebnisse. Forschungsreise in Südafrika Bd 5, Lfg 2. Jena, Denkschriften der Medizinisch-Naturwissenschaftlichen Gesellschaft, 17.

Hartmeyer, R. 1922. Die ascidienfauna des Trondhjemfjords. Meddelese fra Trondhjems Biologiske Station, 14. Kongelige Norske Videnskabers Selskab Skrifter 1921 (6): 1-47.

Hawkins, C.J.; P. Kott \& D.L. Parry. 1983. Vanadium content and oxidation state related to ascidian phylogeny. Comparative Biochemistry and Physiology 76B: 555-558.

Heller, C. 1878. Beitrage zur nahern Kenntniss der Tunicaten. Sitzungsberichte der mathematischnaturwissenschaftlichen Classe der Kaiserlichen Akademie der Wissenschaft Wien 77 (1): 2-28.

HenNIG, W. 1966. Phylogenetic Systematics. Urbana, University of Illinois Press, vol. 3, 263p.

Herdman, W.A. 1880. Preliminary report on the Tunicata of the Challenger expedition. Ascidiidae. Proceedings of the Royal Society of Edinburg 10 (1): 458-72.

Herdman, W.A. 1880. Preliminary report on the Tunicata of the Challenger expedition. Part II. Proceedings of the Royal Society of Edinburg 10: 714-726.

Herdman, W.A. 1881. Preliminary report on the Tunicata of the Challenger expedition. Molgulidae. Proceedings of the Royal Society of Edinburg 11 (4): 233-240.

Herdman, W.A. 1886. Report on the Tunicata collected during the voyage of H.M.S. Challenger during the years 1873-1876. Part II - Ascidiae compositae. Report on the Scientific Results of the Voyage of HMS Challenger 14 (38): 1-399. Herdman, W.A. 1890. On the genus Ecteinascidia and its relations; with descriptions of two new species, and a classification of the family Clavelinidae. Proceedings and Transactions of the Liverpool Biological Society 5: 144-163.

Herdman, W.A. 1899. Descriptive catalogue of the Tunicata in the Australian Museum. Australian Museum, Sydney, Catalogue 17: 1-139.

Herdman, W.A. 1902. Tunicata. In: Report on the collections of natural history made in the Antarctic regions during

Revista Brasileira de Zoologia 25 (2): 269-298, June, 2008 
the voyage of the "Southern Cross". London, p. 190-200.

Herdman, W.A. 1910. Tunicata. In: National Antarctic Expedition (Discovery) 1901-04 (Natural History), London British Museum, vol. 5, p. 1-26.

Hirose, E. 2001. Acid containers and cellular networks in the ascidian tunic with special remarks on ascidian phylogeny. Zoological Science 18: 723-731.

Julin C. 1904. Récherches sur la phylogenèse des tuniciers Archiascidia neapolitana nov. gen. Mitheilungen aus der Zoologischen Station zu Neapel 16: 489-552.

Kesteven, H.L. 1909. Studies on Tunicata 1. Proceedings of the Linnean Society of New South Sales 34: 276-295.

Kornet, D.J. \& H.T. Turner. 1999. Coding polymorphism for phylogeny reconstruction. Systematic Biology 48: 365-379.

Kотт, P. 1957. The ascidians of Australia. II. Aplousobranchiata Lahille: Clavelinidae Forbes \& Hanley and Polyclinidae Verrill. Australian Journal of Marine and Freshwater Research 8: 64-110.

Kотт, P. 1962. The ascidians of Australia. III. Aplousobranchiata Lahille: Didemnidae Giard. Australian Journal of Marine and Freshwater Research 13: 265-334.

Котт, P. 1963. The ascidians of Australia. IV. Aplousobranchia Lahille: Polyclinidae Verrill. Australian Journal of Marine and Freshwater Research 14: 70-118.

Kотт, P. 1969. Antarctic Ascidiacea. A monographic account of the known species based on specimens collected under U.S. Government auspices 1947-1963. Antarctic Research Series 13: 1-239.

Kотт, P. 1972. The ascidians of South Australia. II. Eastern sector of the Great Australian Bight and investigator strait. Transactions of the Royal Society of Australia 96: 165-196.

Kотт, P. 1976. The ascidian fauna of Western Port, Victoria, and a comparison with that of Port Phillip Bay. Memoirs of the National Museum Victoria 37: 53-96.

Котт, P. 1981. Replication in the Ascidiacea: an adaptive strategy in the coral reef environment. Proceedings of the Fourth International Coral Reef Symposium 2: 725-733.

Котт, P. 1983. Two new genera of didemnid ascidians from tropical Australian waters. Beagle 1: 13-19.

Kотт, P. 1985. The Australian Ascidiacea. Part I Phlebobranchia and Stolidobranchia. Memoirs of the Queensland Museum 23: $1-440$.

Kотт, P. 1990. The Australian Ascidiacea. Part II Aplousobranchia (1). Memoirs of the Queensland Museum 29: 1-266.

Котт, P. 1992. The Australian Ascidiacea. Part III Aplousobranchia (2). Memoirs of the Queensland Museum 32: 375-620.

Котт, P. 2001. The Australian Ascidiacea. Part IV Aplousobranchia (3), Didemnidae. Memoirs of the Queensland Museum 47: $1-410$.

Kowalevsky, A. 1874. Ueber die Knospung der Ascidien. Archiv Mikroscopische Anatomie 10: 441-470.

Lahille F. 1887. Sur la classification des tuniciers. Comptes Rendus Hebdomadaires de Séances de L'Academie des
Sciences 102: 1573-1575.

Lahille, F. 1890. Recherches sur les tuniciers des côtes de France. Toulouse, Lagarde et Sebille, 330p.

Lafargue, F. 1983. Évolution des ascidies Didemnidae I: cas des espèces françaises. Vie et Milieu 33: 1-15.

Lafargue, F. \& M. WAHL. 1987. The didemnid ascidian fauna of France. Annales del'Institut Océanographique 63: 1-46.

LESSON, R.P. 1830. Zoologie. In: Voyage autour du monde sur La Coquille pendant 1882-1825, Paris, 2 (1): 256-279, 433440.

Linnaeus, C. 1767. Systema Naturae. Stockholm, $12^{\text {th }}$ ed., vol. 1, part II.

MacDonald, J.D. 1859. On the anatomical characters of a remarkable form of compound Tunicata. Transaction of the Linnean Society of London (Zoology) 22: 373-375.

Michaelsen, W. 1904. Revision der compositen Styeliden oder Polyzoinen. Jahrbuch der Hamburgischen Wissenschaftlichen Anstalten 21 (2): 1-24.

Michaelsen, W. 1924. Ascidiae Krikobranchiae von Neuseeland, den Chatham und den Auckland Inseln. Videnskabelige Meddelelser fra Dansk naturhistoriske Forening I Kobenhavn 77: 263-434.

Michaelsen, W. 1930. Ascidiae Krikobranchiae. Fauna SüdwestAustraliens 5 (7): 463-558.

Michaelsen, W. 1934. The ascidians of the Cape Province of South Africa. Transactions of the Royal Society of South Africa 22 (2): 129-163.

Millar, R.H. 1951. The stolonic vessels of the Didemnidae. Quarterly Journal of Microscopical Science 92: 249-254.

Millar, R.H. 1953a. Ciona. L.M.B.C. Memoirs on Typical British Marine Plants and Animals 35: 1-123.

Millar, R.H. 1953b. On a collection of ascidians from the Gold Coast. Proceedings of the Zoological Society London 123: 277-325.

Millar, R.H. 1954. Pseudodistoma africanum sp. nov., a new compound ascidian from South Africa. Annals and magazine of Natural History (12) 7: 128-132.

Millar, R.H. 1955. On a collection of ascidians from South Africa. Proceedings of the Zoological Society London 125 (1): 169-221.

Millar, R.H. 1960. Ascidiacea. Discovery Reports 30: 1-160.

Millar, R.H. 1961. Euherdmania vitrea, a new species of ascidian from Brazil. Annals and Magazine of Natural History 4: 143-147.

MilLaR, R.H. 1962. Further description of South African ascidians. Annals of the South African Museum 46 (7): 113-221.

Millar, R.H. 1963a. Australian ascidians in the British Museum (Natural History). Proceedings of the Zoological Society London 141: 689-746.

MilLaR, R.H. 1963b. The structure and systematic position of the ascidian Distomus vitreum Sars. Annals and Magazine of Natural History 13: 385-388.

Millar, R.H. 1966. Evolution in ascidians, p. 519-534. In: H. 
BARNES (Ed.). Some contemporary studies in marine science. London, Allen and Unwin, 644p.

Millar, R.H. 1970. British Ascidians (Tunicata, Ascidiacea). London, Academic Press, Synopsis of the British Fauna, New Series, n 1, 92p.

Millar, R.H. 1971. The Biology of Ascidians. Advances in Marine Biology 9: 1-100.

Millar, R.H. 1977. Ascidians (Tunicata: Ascidiacea) from the Northern and North-eastern Brazilian shelf. Journal of Natural History 11 (2): 169-223.

MilLAR, R.H. 1988. Ascidians collected during the International Indian Ocean Expedition. Journal of Natural History 22: 823-848.

Milne-Edwards, H. 1841. Observations sur les ascidies composées des côtes de la Manche. Mémoires de l'Académie des Sciences de l'Institut de France 18: 217-326.

Molina, G.I. 1782. Animali de Chili. In: Saggio sulla storia naturale de Chili. Bologna, $2^{\text {nd }}$ ed.

Monniot, C. 1969. Ascidies récoltées par la Thalassa sur la pente du plateau continental du Golfe de Gascogne. Bulletin du Muséum national d'Histoire naturelle 41: 1131-1145.

Monniot, C. 1969-70. Campagne de la Calypso au large des côtes Atlantiques de l'Amérique du Sud (1961-1962). Première partie (suite). 17. Ascidies Phlébobranches et Stolidobranches. Annales del'Institut Océanographique 36: 3-59.

Monniot, C. 1987. Ascidies de Nouvelle-Calédonie. I: Phlébobranches du lagon. Bulletin du Muséum national d'Histoire naturelle (4), 9 A (1): 3-31.

Monniot, C. 1997. Ascidies phlébobranches du canal du Mozambique. Zoosystema 19: 557-571.

Monniot, C. \& F. Monniot. 1972. Clé mondiale des genres d'ascidies. Archives de Zoologie Expérimentale et Générale 113: 311-367.

Monniot, C. \& F. Monniot. 1983. Ascidies antarctiques et subantarctiques: morphologie et biogéographie. Mémoires du Muséum National d'Histoire Naturelle 125: 4-168.

Monniot, C. \& F. Monniot. 1987a. Some bathyal ascidians from the New Zealand area. New Zealand Journal of Zoology 14: 399-407.

Monniot, C. \& F. Monniot. 1987b. Les ascidies de Polynésie Française. Mémoires du Muséum National d'Histoire Naturelle 136: 1-155.

Monniot, C. \& F. Monniot. 1989. Ascidians collected around the Galapagos Islands using the Johnson-Sea-Link research submersible. Proceedings of the Biological Society of Washington 102 (1): 14-32.

Monniot, C.; Monniot, F. \& P. Laboute. 1991. Coral Reef Ascidians of New Caledonia. Paris, ORSTOM, Collection Faune Tropicale 30, 247p.

Monniot, F. 1983a. Ascidies littorales de Guadeloupe. I: Didemnidae. Bulletin du Muséum National d'Histoire Naturelle (4), 5 A (1): 5-49.

Monniot, F. 1983b. Ascidies littorales de Guadeloupe. III.
Polyclinidae. Bulletin du Muséum National d'Histoire Naturelle (4), 5 A (2): 413-422.

Monniot, F. 1983c. Ascidies littorales de Guadeloupe. V. Polycitoridae. Bulletin du Muséum National d'Histoire Naturelle (4), 5 A (4): 999-1019.

Monniot, F. 1987. Ascidies de Nouvelle-Calédonie. III. Polyclinidae du lagon. Bulletin du Muséum National d'Histoire Naturelle 9: 499-535.

Monniot, F. \& R.H. Millar. 1988. A new genus and species of an aplousobranchiate ascidian (Tunicata, Ascidiacea) from New Caledonia, of uncertain systematic position. Indo-Malayan Zoology 5: 321-327.

Monniot, F. \& C. Monniot. 1996. New collections of ascidians from the western Pacific and southeastern Asia. Micronesica 29: 133-279.

Monniot, F. \& C. Monniot. 2001. Ascidians from the tropical western Pacific. Zoosystema 23: 201-388.

Müeller, O.F. 1776. Zoologiae Danicae. Copenhagen, Prodromus, p. 224-226.

NisHIKAWA, T. 1984. Contributions to the Japanese ascidian fauna XXXVIII. Notes on the morphology and the systematic position of Placentela crystallina Redikorzev from the North Pacific. Proceedings of the Japanese Society of Systematic Zoology 29: 37-56.

NishiKaWA, T. 1991. The ascidians of the Japan Sea. II. Publications of the Seto Marine Biological Laboratory 35: 25-170.

Nixon, K.C. \& J.M. Carpenter. 1993. On outgroups. Cladistics 9: 413-426.

ОкА, А. 1912. On Cyathocormus mirabilis n.gen., sp. nov., the type of a new family of compound ascidians from Japan. Journal of the College of Sciences Imperial University of Tokyo 32 (12): 1-30.

Ока, А. 1926. On a new genus of compound ascidians (Syndiazona nov.gen.). Proceedings of the Imperial Academy Japan 2: 133-5.

ОкА, А. 1933. Ein Fall von KolonialKnospung bei einer Synascidie. Proceedings of the Imperial Academy Japan 9: 436-438.

Notr, J.T. 1892. On the composite ascidians of the Noth Shore Reef. Transactions New Zealand Institut 24: 305-334.

Page, R.D.M. 1996. Treeview: An application to display Phylogenetic trees on personal computers. Computer Applications in the Biosciences 12: 357-358.

PAGE, R.D.M. 2000. NDE $\mathbf{0 . 4 . 8}$ version. Software.

Pérès, J.M. 1946. Remarques sur le polymorphisme des ascidies. Compte-rendu de la Société de Biogéographie, XXI.

Pérès, J.M. 1952. Ascidies de la rôche littorale Corse. Record du Station Marine d'Endoume 6: 35-44.

Perrier, J.O.E. 1898. Note sur la classification de Tuniciers. Comptes Rendus Hebdomadaires de Séances de L'Academie des Sciences 126: 1758-1762.

PhilippI, R.A. 1843. Rhopalaea ein neues Genus der einfachen Ascidien. Archiv für Anatomie und Physiologie 1: 45-47.

Revista Brasileira de Zoologia 25 (2): 269-298, June, 2008 
PHIPPS, C.J. 1774. Voyage au pôle boréale. Appendix 194. London. Redikorzev, V. 1913. Neue Ascidien. Zoologischer Anzeiger 43: 204-213.

Redikorzev, V. 1927. Zehn neue ascidien aus dem fernen Osten. Zoologische Jahrbücher 53: 373-404.

Renier, S.A. 1804. Prospetto della classe dei vermi. p. 15-27 (Padua) fide Porro C. 1840, Nota per una Bibliografia Malacologie, Series III Geografica n 1-4, p. 1-3 and numbered columns 27-130.

RitTER, W.E. 1899. A contribution to the knowledge of the tunicates of the Pribilof Islands, p. 511-537. In: DS HirdabM (Ed.). Fur seals and fur-seal islands of the north Pacific ocean. Washington, Part 3.

RitTeR, W.E. 1903. The structure and affinities of Herdmania claviformis, the type of a new genus and family of ascidians from the coast of California, p. 237-261. In: Mark anniversary volume. New York, Henry Holt.

Ritter, W.E. 1904. Euherdamania vs. Herdmania preoccupied. Zoologischer Anzeiger 27: 650-651.

RitTer, W.E. \& R.A. Forsyth. 1917. Ascidians of the littoral zone of southern California. University of California Publications in Zoology 16: 439-512.

Ruppert, E.E. 1997. Cephachordata (Acrania), p. 349-504. In: F.W. HARRISON (Ed.). Microscopic anatomy of invertebrates. New York, Wiley-Liss, vol. 15, 504p.

SARS, M. 1851. Beretning om en i Sommeren 1849, foretagen zoologiske Reise i Lofoten og Finmarken. Nytt Magasin for Naturvidenskapene 6: 121-211.

SAviGNY, J.C. 1816. Recherches anatomiques sur les ascidies composées et les ascidies simples. Système de la classe des ascidies. In: Mémoires sur les animaux sans vertèbres. Paris, G. Dufour, part 2, 239p.

SLUITER, C.P. 1885. Ueber einige einfachen ascidien von der Insel Billiton. Natuurkundig Tijdschrift voor Nederlandsch Indie 45: 160-232.

SLuiter, C.P. 1898. Tuniciers récueillis en 1896 par La Chazalie dans la Mers des Antilles. Mémoires de la Sociéteé Zoologique de France 11: 5-34.

Sluiter, C.P. 1904. Die tunicaten der Siboga-Expedition. Part I Die socialen und holosomen ascidien. Siboga Expedition 56: $1-126$.

Sluiter, C.P. 1909. Die tunicaten der Siboga-Expedition. Part II - Die merosomen ascidien. Siboga Expedition 56B: 1-112.

Stach, T. \& J.M. Turbeville. 2002. Phylogeny of Tunicata inferred from molecular and morphological characters. Molecular Phylogenetics and Evolution 25: 408-428.

Stimpson, W. 1852. Several new ascidians from the coast of the United States. Proceedings of the Boston Society of Natural History 4: 228-232.

Stimpson, W. 1855. Descriptions of some new marine invertebrates. Proceedings of the Academy of Natural Sciences of Philadelphia 7: 387-388.

Swalla, B.J. 2001. Phylogeny of the Urochordates: implications for Chordate Evolution, p. 219-224. In: H. SAWADA; H. Yokosawa \& C.C. Lambert (Eds). The Biology of Ascidians. Tokyo, Springer-Verlag, 470p.

Swalla, B.J.; C.B. Cameron; L.S. Corley \& J.R. Garey. 2000. Urochordates are monophyletic within the Deuterostomes. Systematic Biology 49: 52-64.

Swofford, D.L. 2002. PAUP* 4. Beta version 10 for Microsoft Windows. Smithsonian Institution.

Токіока, Т. 1955. Contributions to Japanese ascidian fauna XI. Sporadic memoranda (2). Publications of the Seto Marine Biological Laboratory 4 (2, 3): 205-222.

Токіока, T. 1967. Pacific Tunicata of the United States National Museum. Bulletin of the United States National Museum 251: 1-242.

Trason, W.B. 1957. Larval structure and development of the oozooid in the ascidian Euherdmania claviformis. Journal of Morphology 100: 509-545.

Trason, W.B. 1963. The life cycle and affinities of the colonial ascidian Pycnoclavella stanleyi. University of California Publications in Zoology 65: 283-326.

Trausteut, M.P.A. 1883. Vestindiske ascidiae simplices. Anden Afdeling. Mogulidae og Cynthiadae. Videnskabelige Meddelelser fra Dansk naturhistoriske Forening I Kobenhavn 1882: 108-136.

Turbeville, J.M.; J.R. Schulz \& R.A. Ralf. 1994. Deuterostome phylogeny and the sister group of the chordates: Evidence from molecules and morphology. Molecular Biology and Evolution 11: 648-655.

Turon X. 1991. Morphology of the adhesive papillae of some ascidian larvae. Cahiers de Biologie Marine 32: 295-309.

Turon, X. \& López-Legentil S. 2004. Ascidian molecular phylogeny inferred from mtDNA data with emphasis on the Aplousobranchiata. Molecular Phylogenetics and Evolution 33: 309-320.

VAN NAmE, WG. 1902. The ascidians of the Bermuda Islands. Transactions of the Connecticut Academy of Arts and Sciences 11: 325-412.

VAN NAME, WG. 1918. Ascidians of the Philippines and adjacent waters. United States National Museum Bulletin 100 (1): 49-174.

VAN NAME, WG. 1921. Ascidians of the West Indian region and south eastern United States. Bulletin of the American Museum of Natural History 44: 283-494.

VAN NAME, WG. 1924. Ascidians from Curaçao. Bijdragen tot de kennis der fauna van Curaçao, Resultaten einer Reis van Dr. C.J. Van der Horst in 1920, Bijdragen tot Dierkunde 23: 23-32.

VAN NAME, WG. 1945. The North and South American ascidians. Bulletin of the American Museum of Natural History 84: $1-476$.

VAsseur, P. 1969. Deuxième contribution a l'étude des ascides de Madagascar région de Tuléar. Bulletin du Muséum National d'Histoire Naturelle, Sér. 2, 40 (5): 912-933. 
VERRILL, A.E. 1871. Descriptions of some imperfectly known and new ascidians from New England. American Journal of Science (3) 1: 288-294, 443-446.

WADA, H. 1998. Evolutionary history of free-swimming and sessile lifestyles in urochordates as deduced from $18 \mathrm{~S}$ rDNA molecular phylogeny. Molecular Biology and Evolution 15: 1189-1194.

Wada, H.; K.W. Makabe; M. Nakauchi \& N. Satoh. 1992. Phylogenetic relationships between solitary and colonial ascidians, as inferred from the sequence of the central region of their respective 18S rDNAs. Biological Bulletin 183: 448-455.
Wiegmann, A.F.A. 1835. Tunicata. Archiv für Naturgeschichte 1 (1): 309.

Wiley, E.O. 1981. Phylogenetics. The Theory and Practice of Phylogenetic Systematics. New York, John Wiley, 439p.

Wiley, E.O.; D. Siegel-Causey; D.R. Brooks \& V.A. Funk. 1991. The compleat cladist: a primer of phylogenetic procedures. The University of Kansas Museum of Natural History 19: 1-158

Submitted: 19.VII.2007; Accepted: 16.VI.2008.

Editorial responsibility: Georgina Bond-Buckup

Appendix 1. List of species and specimens studied.

Stolidobranchia

Pyura chilensis Molina, 1782 - DZUP PYU 41, Chile, NMNH 16637, Terra do Fogo, Argentina, 02/08/1971; P. discoveryi (Herdman, 1910) - NMNH 14300, South Orkney Islands, Antartic, 14/04/1964, DZUP PYU 1, Shetland del Sur, Antartic, 01/1995, IO-USP (Proantar V), 14/02/1987; P. vittata (Stimpson, 1852) - NMNH 15056, DZUP PYU 22, Ilha Bela, São Paulo, Brazil, 16/02/1997.

Molgula occidentalis Traustedt, 1883 - NMNH 2734, North Carolina, USA, 20/10/1885. M. pedunculata Herdman, $1881-\mathrm{NMNH}$ 18023, Bransfield Strait, Antartic, 01/04/1983, DZUP MOLG 1, South Shetland, Antartic, 06/1994. IO-USP (Proantar XVI), Summer 1997/1998. M. phytophila Monniot, 1969-70 - DZUP MOLG 8, Guaratuba, Paraná, Brazil, 08/08/1998.

Phlebobranchia

Ascidia mentula Müller, 1776 - DZUP ASC 20 (NMNHUVIGO M0203), Ria de Ferrol, Galícia, Spain, 11/07/1988, NMNH 220 Scotland, Strathclyde, 1884; A. sydneiensis Stimpson, 1855 - DZUP ASC 11, Penha, Santa Catarina, Brazil, 08/06/1998; A. interrupta Heller, 1878 - DZUP ASC 15, São Sebastião, São Paulo, Brazil, 17/11/1994.

Perophora listeri Forbes, 1848 - NMNH 3035, Mediterranean Sea, Napole, Italy, 1893; P. multiclathrata (Sluiter, 1904) - DZUP PEROPH 10, Guaratuba, Paraná, Brazil, 20/02/2000; P. viridis Verrill, 1871 - DZUP PEROPH 7, Itapema, Santa Catarina, Brazil, 13/10/1996.

Ecteinascidia turbinata Herdman, 1880 - DZUP ECT 01, Marina Puerto Del Sol, Cayo Largo, Cuba, 09/11/1997.

Aplousobranchia

Ciona intestinalis (Linnaeus, 1767) - DZUP CION 02 (UVIGO M0509), Ria de Ferrol, Galícia, Spain, 11/07/1988, CION 03, Mediterranean Sea, France, 07/1992; C. antarctica Hartmeyer, 1911 - NMNH 13739, 26/01/1972 e 13740, 26/09/1979, Antartic; C. pomponiae Monniot and Monniot, 1989 - NMNH 18247 Holotype, Galapagos Islands, 21/11/1986.

Rhopalaea abdominalis (Sluiter, 1898) - NMNH 20831, Belize, 08/1994; R. crassa (Herdman, 1880) - MNHN P1RHO A22 (slide P1162), Mozambique, 18/11/1996.

Diazona violacea Savigny, 1816 - DZUP DIAZ 02 (UVIGO Fauna II 09.165A), Cabo Peñas, Asturias, N Spain, NMNH 3030, Napoles, Italy, 1893; D. chinensis (Tokioka, 1955) - MNHN P1DIA10 (permanent slides P1-122, P1-125), Manado, Sulawesi, Indonesia; D. textura Monniot,C. 1987 - MNHN P1DIA13 Holotype (permanent slides P1-98, P1-99), Vauban 376, New Caledonia.

Tylobranchion speciosum Herdman, 1886 - NMNH 018526, South Shetland Island, Antartic, 16/01/1972, IO-USP (Proantar XVI), 11/03/1997, DZUP DIAZ 03 (11/03/1997, Proantar XVI, IO-USP), Antartic.

Stomozoa gigantea (Van Name, 1921) - DZUP STOM 01, Salvador, Bahia, Brazil, 03/08/1999, NMNH 15684.

Pycnoclavella stanleyi Berrill and Abbott, 1949 - NMNH 17616, 24/05/1986 and 17617, 25/05/1986 California, USA.

Clavelina lepadiformis Müller, 1776 - DZUP POLY 50 (UVIGO 12212), Ria de Ferrol, Galícia, Spain, 30/07/1988; C. oblonga Herdman, 1880 - NMNH 7148, Florida, USA, 03/04/1887, DZUP POLY 25, Arraial do Cabo, Rio de Janeiro, Brazil, 13/04/1993; C. steenbrasensis Millar, 1955 - SAM A25948 (UPE 98-136), Port Elizabeth, Algoa Bay, South Africa, 04/10/1998, SAM A25949 (EL 99-030), East London, Harbour, South Africa, 09/02/1999.

Nephtheis fascicularis (Drasche, 1882) - MNHN A3OXY2, New Caledonia, permanent slides: A3-606 New Caledonia and A3-626 Indonesia, NMNH 20137, Vietnam, Nha Trang Bay, South China Sea, 16/07/1990.

Polycitor crystallinus Renier, 1804 - MNHN A3POL A 16, New Caledonia, 1987, permanent slide A3 558; P. circes Michaelsen, 1930 - MNHN A3POL A 7, Sulawesi, Manado, Indonesia, permanent slides A3-644, A3-646; P. vitreus (Sars, 1851) - NMNH 854, Newfoundland, Canada, 22/08/1886.

Exostoma ianthinum (Sluiter, 1909) - MNHN A3EXO1, permanent slide A3-801, Palau, 22/06/1993, NMNH 6028, 6029 Filipinas, Sulu Archipelago, 14/02/1908.

Revista Brasileira de Zoologia 25 (2): 269-298, June, 2008 
Eudistoma olivaceum (Van Name, 1902) - MNHN A3EUD16, Guadeloupe, permanent slide A3-328; E. recifense Millar, 1977 - DZUP POLY 52 (PALB 48PE-RE), Recife, Pernambuco, Brazil; E. vannamei Millar, 1977 - DZUP POLY 51 (PALB 46AL-MA), Marechal Deodoro, Alagoas, Brazil; Eudistoma sp. - DZUP POLY 53 Mont Serrat, Salvador, Bahia, BRAZIL 05/08/1999.

Euherdmania claviformis (Ritter, 1903) - NMNH 17600, California, USA, 24/05/1986, MNHN A1EUH10, New Caledonia (permanent slide A1-1148 WA 137NCZO); E. vitrea Millar, 1961 - DZUP POCL 19, Ilha do Arvoredo, Santa Catarina, Brazil, 14/11/1998; Euherdmania sp. - DZUP POCL 21, Ilha do Arvoredo, Santa Catarina, Brazil, 28/11/1998.

Pseudodistoma cereum Michaelsen, 1924 - MNHN A1 PSEU02 (permanent slides A1 223, A1 224), Senegal, 1950; P. crucigaster Gaill, 1972 - NMNH 1006176, NMNH 1006179, Balearic Islands, Mediterranean, 10/1999; P. cyrnusense Pérès, 1952 - NMNH 1006180, Balearic Islands, Mediterranean, 10/1999; P. africanum Millar, 1954 - SAM A25950 (UPE 98-054), Port Elizabeth, Algoa Bay, South Africa, 01/10/1998.

Placentela crystallina Redikorzev, 1913 - NMNH 20354, Mar de Okhotsh, Russia, 30/07/1991; P. translucida Kott, 1969 - NMNH 11978 paratype, Adelaide Island, Antartic Peninsula, 26/10/1962.

Ritterella aequalisiphonis (Ritter \& Forsyth, 1917) - NMNH 17599, California, USA, 25/05/1986; R. mirifica Monniot and Monniot, 1983 - Holotype NMNH 14492, 15/03/1964 Holotype, 15/03/1964, Antartic, Joinville Island, MNHN A1RIT05 permanent slide A1 890, Eltanin; R. dispar Kott, 1957 - MNHN A1RIT01 (permanent slide A1 505), Mozambique.

Monniotus ramosus Millar, 1988 - NMNH 18471, paratype, Mozambique, 19/08/1964.

Synoicum adareanum (Herdman, 1902) - NMNH 17817, IO-USP (Proantar V), 14/02/1987, Antartic; S. jordani (Ritter, 1899) NMNH 18625, Alaska, USA; S. partitionis Monniot, 1987 - MNHN A1 1154, Canal Woodin, New Caledonia.

Polyclinum constellatum Savigny, 1816 - NMNH 17380, México, 12/04/1960, DZUP POCL 23, Penha, Santa Catarina, Brazil, 21/05/ 1999, (permanent slide 1.13, Praia Grande, São Paulo, BRAZIL, 18/11/1991); P. aurantium Milne-Edwards, 1841 - DZUP POCL 26 (UVIGO 11003), Ria de Ferrol, Galícia, Spain, 20/02/1988; P. pute Monniot and Monniot, 1987b - MNHN A1POL B 34 (permanent slides A1-1034 tipo), Tikelau Polynesie.

Aplidium lobatum Savigny, 1816 - MNHN A1APL B284 (permanent slides A1 1138, A1 1174), New Caledonia; A. accarense (Millar, 1953b) - DZUP POCL 24, Penha, Santa Catarina, Brazil, 19/03/1999; A. flavolineatum Monniot, 1987 - SAM A25951 (UPE 2000-003), Port Elizabeth, Algoa Bay, South Africa, 14/02/2000.

Distaplia cylindrica Lesson, 1830 - NMNH 18879, South Georgia Island, Antartic, 05/12/1986, DZUP POLY 60 (Proantar VIII, IO-USP), Antartic; D. bermudensis Van Name, 1902 - NMNH 6945, Florida, USA, 02/1887, DZUP POLY 28, São Sebastião, São Paulo, Brazil, 12/02/1997; D. skoogi Michaelsen, 1934 - SAM A25952 (UPE 98-063), Port Elizabeth, Algoa Bay, South Africa, 03/10/1998.

Hypsistozoa fasmeriana Michaelsen, 1924 - NMNH 17205, Balleny Islands, Antartic.

Diplosoma listerianum (Milne-Edwards, 1841) - DZUP DID 88, Penha, Santa Catarina, Brazil, 16/01/1998; D. macdonaldi (Herdman, 1886) - EJ-66-439, Baía de Tampa, Florida, USA, 1966 (Hourglass Cruises); D. glandulosum Monniot, F 1983a - NMNH 15396, Belize, 14/03/1983.

Lissoclinum aureum Verrill, 1871 - NMNH 4754, Massachusetts, USA, 17/09/1878. L. fragile Van Name, 1902 - NMNH 7251, Virgin Islands, Caribbean Sea; L. perforatum Van Name, 1902 - DZUP DID 110, Ilha do Arvoredo, Santa Catarina, Brazil, 28/11/1998.

Polysyncraton chondrilla (Michaelsen, 1924) - NMNH 12223, S. Shetland Islands, Antartic; P. amethysteum Van Name, 1902 NMNH 20035, São Sebastião, São Paulo, Brazil, 12/03/1986.

Didemnum candidum Savigny, 1816 - NMNH 7385, Sulu Archipelago, Philippines, 24/02/1908; D. fusiferum Van Name, 1921 NMNH 6954, Florida, USA, 02/1881, EJ-66, Tampa Bay, Florida, USA, 1966 (Hourglass Cruises); D. vanderhorsti Van Name, 1924 - DZUP DID 107, Ilha do Arvoredo, Santa Catarina, Brazil, 15/11/1998.

Trididemnum orbiculatum (Van Name, 1902) - permanent slides DZUP DID 2.2, Itapema, Santa Catarina, Brazil, 22/10/1994, DID 2.4, São Sebastião, São Paulo, Brazil, 04/11/1991; T. cerebriforme Hartmeyer, 1913 - SAM A25953 (SAF 96-052), 24/04/1996, SAM A25954 (PLET 2000-009), 23/03/2000, South Africa; T. hians Monniot, F 1983a - EJ-67, Tampa Bay, Florida, USA, 1966 (Hourglass Cruises).

Leptoclinides faeroensis Bjerkan, 1905 - NMNH 3750, Nova Scotia, Canada; L. hawaiiensis Tokioka, 1967 - NMNH 11793 paratype, Auau Channel, between Maui e Lanai, Hawaii, USA; L. rufus (Sluiter, 1909) - NMNH 17231, 12/12/1962, Terra do Fogo, Argentina.

Atriolum quadratum Monniot and Monniot, 1996 - MNHN OCDN 1442-T, holotype (permanent slides I2-1583, A2-1582), Chuuk Island; A. marinense Kott, 2001 - NMNH 1845, 15/10/1964, Mozambique, Madagascar, SAM A25955 (UPE 2000-080), Port Elizabeth, Algoa Bay, South Africa, 15/03/2000.

Tylobranchion nordgaardi (Hartmeyer, 1922) - MNHN P1 TYL 2, Golfo de Gascogne, Thalassa, France, 1968, permanent slide of the pharynx (T 451-PI-9, Thalassa, 1967).

Tetrazona porrecta Millar, 1962 - SAM A25956 (UPE 99-012), 17/02/1999, SAM A25957 (UPE 2000-075), 14/03/2000, Port Elizabeth, Algoa Bay, South Africa.

Revista Brasileira de Zoologia 25 (2): 269-298, June, 2008 
Species evaluated using only literature information

Branchiostoma lanceolatum (Pallas, 1774): RUPPERT (1997)

Ecteinascidia diaphanis Sluiter, 1885: Koтा (1985)

Stomozoa australiensis Kott, 1990: Котт (1990); S. bellissima Kott, 1990: Koтt (1990)

Pycnoclavella aurilucens Garstang, 1891: Garstang (1891), Millar (1970); P. minuta Millar, 1953b: Millar (1953b); P. diminuta (Kott, 1957): KOTT (1957, 1990), MLLLAR (1963)

Euclavella claviformis (Herdman, 1899): Котт (1990)

Brevicollus tuberatus Kott, 1990: Koтt (1990)

Anadistoma attenuatum Kott, 1992: Котт (1992)

Dumus areniferus Brewin, 1952: BreWIN (1952), KotT (1976, 1992), MonNIOT (1987); D. dumosus Monniot, 1987: MonNIOT (1987)

Monniotus australis (Kott, 1957): Котт (1957, 1992); M. radiatus Kott, 1992: Котт (1992)

Protopolyclinum pedunculatum Millar, 1960: MiLLAR (1960)

Neodistoma mammillatum Kott, 1990: Котт (1990)

Hypsistozoa obscura Kott, 1969: Котт (1969); H. distomoides (Herdman, 1899): Котт (1990)

Polysyncraton millepore Vasseur, 1969: Котт (2001)

Atriolum robustum Kott, 1983: Котт $(1983,2001)$

Revista Brasileira de Zoologia 25 (2): 269-298, June, 2008 